\title{
Assessment of precipitation climatology in an ensemble of CORDEX-East Asia regional climate simulations
}

\author{
Bo Huang*, Stefan Polanski, Ulrich Cubasch \\ Institute of Meteorology, Freie Universität Berlin, Carl-Heinrich-Becker-Weg 6-10, 12165 Berlin, Germany
}

\begin{abstract}
An ensemble of regional climate simulations from the Coordinated Regional Downscaling Experiment in East Asia (CORDEX-East Asia) was analysed to evaluate the ability of 5 regional climate models (RCMs) and their ensemble mean in reproducing the key features of present-day precipitation (1989-2008). We emphasised (1) an extreme rainfall event, (2) seasonal climatology, (3) annual cycles and inter-annual variability and (4) the monsoon characteristics. We highlighted 4 sub-monsoon regions, viz. South Asian Summer Monsoon (SAS), the East Asian Summer Monsoon (EAS), the Western North Pacific Tropical Monsoon (WNP) and the AustralianMaritime Continent Monsoon (AUSMC). We found that the RCMs showed a reasonable performance to capture the extreme rainfall event in 1998. The RCMs simulated the seasonal mean, annual cycle and inter-annual variability acceptably. However, individual models exhibited significant biases in some sub-regions and seasons. Moreover, most of the RCMs significantly improved their performance in capturing precipitation climatology and monsoon characteristics over the Korean Peninsula, the Korea Strait and southern Japan. Based upon this performance study, we conclude that the present set of RCMs from CORDEX can be used to provide useful information on climate projections over East Asia.
\end{abstract}

KEY WORDS: CORDEX-East Asia $\cdot$ Regional climate model $\cdot$ Ensemble simulations $\cdot$ Precipitation climatology $\cdot$ Monsoon characteristics

\section{INTRODUCTION}

Recent climate change and its feedback to human activities have become increasingly important, especially in monsoon regions (IPCC 2013). However, understanding changes in monsoon climate is still challenging for climate research, due to uncertainty parameters such as circulation and precipitation (Christensen et al. 2013). Coupled general circulation models (CGCMs) or Earth system models (ESMs) are used as primary tools to analyse the large-scale feedback in climate systems (Hargreaves \& Annan 2014), but model performance strongly depends on the region (Flato et al. 2013). Regional climate models (RCMs) based upon dynamical downscaling of CGCMs/ESMs are more appropriate for capturing

\footnotetext{
${ }^{*}$ Corresponding author: huangb@zedat.fu-berlin.de
}

sub-grid scale meteorological processes (e.g. sea breezes, mountain precipitation etc.) over heterogeneous land surfaces, according to high-resolution surface forcing (Hong \& Kanamitsu 2014). RCM performance is strongly dependent on boundary conditions (Staniforth 1997, Laprise 2008, Rummukainen 2010), its domain sizes (Leduc \& Laprise 2009) and its horizontal resolution (Gao et al. 2006), especially in steeply orographic regions, in order to capture subgrid scale processes (Nikulin et al. 2012, Hong \& Kanamitsu 2014). Additionally, the parameterization scheme is the basis of climate modelling, which plays an increasingly important role in RCM performance with increasing model resolution (Lee et al. 2013, Hong \& Kanamitsu 2014, Lee \& Hong 2014). Accurately evaluating the degree of added value in the

(C) The authors 2015. Open Access under Creative Commons by Attribution Licence. Use, distribution and reproduction are unrestricted. Authors and original publication must be credited. 
RCM against the corresponding GCM result has remained under debate in the last few years (Hong \& Kanamitsu 2014). Therefore, a comprehensive assessment of the performance of RCMs is key for regional climate dynamical downscaling.

RCM studies generally tend to over- or under-estimate monsoon precipitation and temperature when compared to observations ( $\mathrm{Fu}$ et al. 2005, Xue et al. 2010, Nikulin et al. 2012, Gbobaniyi et al. 2014). In this regard, it is important to evaluate the capability of RCMs to reproduce the present climate before using them for future scenarios (Wang et al. 2004, Flato et al. 2013), especially in monsoon regions (Fu et al. 2005, Nikulin et al. 2012). In the last decade, numerous international RCM downscaling projects have been carried out focusing on monsoons, but over specific areas of interest (Laprise 2008, Giorgi et al. 2009). These projects include the Regional Model Intercomparison Project for Asia (RMIP Asia; Fu et al. 2005) to evaluate and improve RCM simulations for the East Asian monsoonal region, the African Monsoon Multidisciplinary Analyses (AMMA; Redelsperger et al. 2006, Ruti et al. 2011) to address the main uncertainties in the atmospheric processes controlling the monsoon system (Hourdin et al. 2010) and the West African Monsoon Modelling and Evaluation (WAMME; Druyan et al. 2010, Xue et al. 2010) to study the role of land-atmosphere-aerosol interactions on West African monsoon processes. Each of these projects has made significant contributions to improve RCM simulations and to understand the evolution of monsoon mechanisms. However, the projects have been limited by international coordination and by the limited transfer of knowledge between the projects and the regions of interest. A worldwide inter-model comparison project with a common framework (i.e. the Coordinated Regional Climate Downscaling Experiment, CORDEX) was set up with the aim of obtaining comprehensive RCM data to study regional climate change (Giorgi et al. 2009). Among the focus areas within CORDEX is East Asia, which is characterised by a complex monsoon system (Ding \& Chan 2005, Hui \& Shum 2005) and a heterogeneous land cover (Fu et al. 2005, Gao et al. 2006). Furthermore, the application of RCMs is particularly important over East Asia due to their better performance in reproducing the present monsoon climate. In addition, these models provide more reliable climate change signals over that region due to their high spatial resolutions (Gao et al. 2006, 2013, Qian \& Leung 2007, Yu et al. 2010).

Several studies have examined the performance of a single RCM in simulating precipitation over
CORDEX-East Asia (CORDEX-EA). For example, COSMO-CLM (Rockel et al. 2008) is able to capture precipitation patterns in a small river basin (Fischer et al. 2013), but has a significant wet bias over steep orographic regions (Wang et al. 2013). RegCM (Giorgi et al. 1993) shows close agreement with the observed precipitation (Gao et al. 2006, 2011), but a large positive bias over northern Asia during the cold season (Giorgi et al. 2012), the performance of which is substantially dependent on model resolution (Gao et al. 2008) and geographical regions (Gao et al. 2012, Oh et al. 2014). YSU-RSM (Hong et al. 2013) models the inter-annual variations of precipitation as well as extreme precipitation events (Lee et al. 2014). These RCMs can represent the main climatological features of precipitation at different levels of accuracy (Giorgi et al. 2012, Wang et al. 2013, Lee et al. 2014, Oh et al. 2014). However, none of these studies focused on an inter-comparison of the different models in simulating precipitation in this region.

Here we present the first evaluation results of the CORDEX-EA project using an ensemble of 5 RCM simulations driven by the ERA-Interim re-analysis data from the European Centre for Medium-Range Weather Forecasts (ECMWF; Dee et al. 2011). We examined the capacity of the individual RCMs and their multi-model ensemble (MME) means to reproduce the present climatology and to capture the Asian-Australian monsoon system.

\section{MODELS, DATA AND METHODS}

Five RCMs participate in CORDEX-EA (Table 1). Following the modelling framework of the CORDEX project, the simulations are driven by ERA-Interim re-analysis data (1989-2008) at the lower and lateral boundaries, and are integrated over East Asia (Fig. 1) with a spatial horizontal resolution of $0.44^{\circ}(\sim 50 \mathrm{~km})$. The CORDEX-EA domain includes 4 sub-monsoon systems (i.e. the South Asian Summer Monsoon [SAS], the East Asian Summer Monsoon [EAS], the Western North Pacific Tropical Monsoon [WNP], and the Australian-Maritime Continent Monsoon [AUSMC]; Fig. 1; Christensen et al. 2013).

COSMO-CLM (COSMO: the Consortium for Small-scale Modelling; CLM: Climate Limited-area Modelling or the climate version of 'Lokalmodell'; www.clm-community.eu) is a non-hydrostatic regional climate model, which has an Arakawa-C horizontal grid (Arakawa \& Lamb 1981) and a terrain following height coordinates (Schär et al. 2002) with rotated geographical coordinates in the vertical level. 


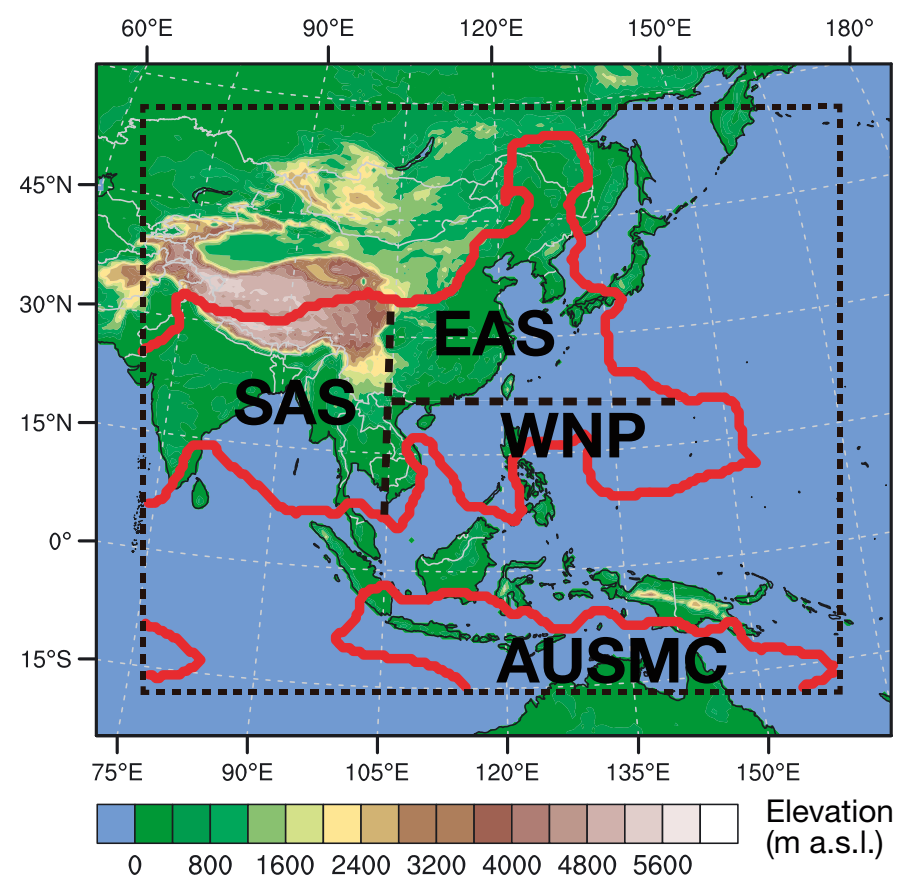

Fig. 1. CORDEX-East Asia domain at $0.44^{\circ}$ grid resolution with topography and the 4 sub-monsoon domains including the South Asian Summer Monsoon (SAS), the East Asian Summer Monsoon (EAS), the Western North Pacific Tropical Monsoon (WNP) and the Australian-Maritime Continent Monsoon (AUSMC)

Wang et al. (2013) adapted the COSMO-CLM in East Asia, but it is driven by the ERA-40 re-analysis (Uppala et al. 2005). Following the CORDEX-EA framework, we re-ran the simulation driven by the ERA-Interim. The model set-up was adapted from Wang et al. (2013), but using the Runge-Kutta splitexplicit scheme for time integration and a time step of $240 \mathrm{~s}$. The physical parameterization schemes used in the simulation are the Tiedtke mass-flux convection scheme (Tiedtke 1989), the prognostic turbulent kinetic energy (TKE) turbulence scheme, the $\delta$ 2 -stream radiation scheme with full cloud-radiation feedback (Ritter \& Geleyn 1992) and the multi-layer soil scheme (Jacobsen \& Heise 1982).

HadGEM3-RA is a regional version of the atmospheric component of the Hadley Centre Global Environment Model (HadGEM3-A). It is a non-hydrostatic regional climate model, which has an Arakawa-C horizontal grid and a terrain-following vertical coordinate. The model includes semi-Lagrangian advection of all prognostic variables except density, permitting relatively long time steps to be used at high resolution (Davies et al. 2005, Martin et al. 2006). The simulation was set up with the general 2-stream radi- 
ation scheme (Edwards \& Slingo 1996, Cusack et al. 1998), the nonlocal mixing scheme for unstable layers (Lock et al. 2000), the local Richardson number scheme for stable layers (Smith et al. 1990), the mixed phase microphysics scheme (Wilson \& Ballard 1999), the revised mass flux scheme (Gregory \& Rowntree 1990) for deep and shallow convection (Grant \& Brown 1999), the MOSES-II with 9 surface tile types plus coastal tiling (Essery et al. 2003) for land surface and the Smith et al. (1990) scheme using parameterized critical relative humidity (RH-crit) for cloud cover (Cusack et al. 1998).

The new version of the RegCM regional climate modelling system version 4 (RegCM4) is a hydrostatic, compressible model with sigma-p vertical coordinates and an Arakawa-B horizontal grid (Giorgi et al. 2012). The dynamical core of RegCM4 is the same as the Pennsylvania State University/ National Centre for Atmospheric Research (PSU/ NCAR) meso-scale model (MM5) (Grell et al. 1994). The parameterization scheme of this study includes the MIT-Emanuel cumulus scheme (Emanuel 1991, Emanuel \& Zivkovic-Rothman 1999), modified Holtslag planetary boundary layer scheme (Holtslag et al. 1990), NCAR Community Climate Model version 3 (CCM3) radiation scheme (Kiehl et al. 1996) and NCAR Community Land Model version 3.5 (CLM3.5) land surface scheme (Bonan et al. 2002, Steiner et al. 2009).

SNU-MM5 is an evolved version of MM5 (Lee et al. 2004), which implements the spectral nudging technique of von Storch et al. (2000) for lateral boundary handling. It uses a non-hydrostatic primitive equation system with a terrain-following sigma vertical coordinate. The Kain-Fritsch cumulus convective parameterization scheme (Kain \& Fritsch 1990), the Reisner II explicit moisture scheme (Reisner et al. 1998), the CCM2 radiative transfer scheme (Briegleb 1992), the CLM3 land surface model (Bonan et al. 2002) and the Yonsei University planetary boundary layer (YSUBL) scheme (Hong et al. 2006) were configured in this study.

The perturbation model YSU-RSM is described by a 2-dimensional sine series for the perturbation of vorticity, but by a 2-dimensional cosine series for perturbations of pressure, divergence, temperature and mixing ratio. Linear computations of horizontal diffusion and semi-implicit adjustment are only considered as perturbations, thus the error due to the reevaluation of the linear forcing from the base fields is eliminated (Juang \& Kanamitsu 1994, Juang et al. 1997). Lee et al. (2014) presented details of the parameterization scheme for the simulation.
For model evaluation of precipitation climatology and monsoon characteristics, the Asian Precipitation-Highly-Resolved Observational Data Integration Towards Evaluation of the Water Resources (APHRODITE; Yatagai et al. 2009), the Climatic Research Unit (CRU; Harris et al. 2014), the Global Precipitation Climatology Centre (GPCC; Schneider et al. 2014), the Global Precipitation Climatology Project (GPCP; Adler et al. 2003), the Tropical Rainfall Measuring Mission (TRMM; Huffman et al. 2007) and the ERA-Interim re-analysis datasets were used (Table 2). In addition, low-level wind fields (850 $\mathrm{hPa}$ ) from the ERA-Interim were compared against model results. To eliminate the small difference in the assimilation approach in order to derive the ERA-Interim precipitation, we followed Nikulin et al. (2012) with base times 00:00 and 12:00 h UTC and forecast steps of $12 \mathrm{~h}$ to obtain the daily precipitation. We then calculated the daily and monthly means. It is worth mentioning that the difference between APHRODITE, CRU and GPCC is not significant in terms of climatology. The pattern correlation coefficient between APHRODITE and CRU (GPCC) climatology is $0.96(0.97)$ for annual mean, 0.96 (0.96) for MAM, 0.95 (0.97) for JJA, $0.96(0.97)$ for SON and 0.97 (0.97) for DJF. Therefore, a merged APHRODITE, CRU and GPCC dataset was used to compare monsoon characteristics in CORDEX-EA. These precipitation datasets cover the time period from 1989-2008, except APHRODITE (1989-2007) and TRMM (1998-2008). The validation data are remapped onto a common grid of $0.44^{\circ}$ by bi-linear interpolation.

We used 3 different skill measurements to validate the performance of the RCMs on a seasonal time scale for summer (JJA) and winter (DJF) from 19892008: the mean bias (BIAS), the pattern correlation coefficient (PCC) and the root mean square error (RMSE).

In addition, we calculated the 4 monsoon metrics defined by Wang \& Ding (2008). These metrics contribute to a new monsoon index which is based on the physical processes of the coupled atmosphere-ocean-land system and its response to solar radiative forcing (Wang et al. 2011). Four parameters are used for this index: (1) the annual mean precipitation $(\mathrm{AM}) ;(2+3)$ the first and second annual cycle modes of the annual variation of the precipitation (AC1 and AC2); and (4) monsoon precipitation intensity and monsoon domain (MPI and monsoon domain) (Wang et al. 2011, Lee \& Wang 2014). Following Lee \& Wang (2014), we analysed the 4 parameters of each model simula- 


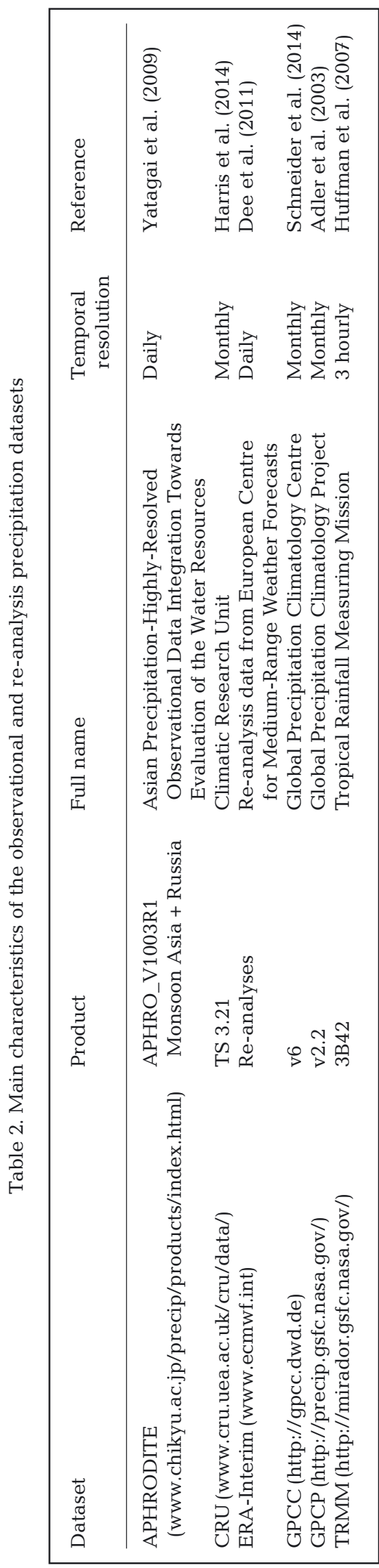

tion and MME to evaluate the capacities of the models in reproducing the Asian monsoon system. The PCC and the normalised RMSE (NRMSE) were used to evaluate the models' capacities. The NRMSE is defined as the RMSE normalised by the standard deviation of observations that is calculated with reference to the regional mean of CORDEX-EA.

\section{RESULTS}

\subsection{Extreme rainfall event}

We first checked the ability of each model to simulate an extreme rainfall event which caused severe flooding in the Yangtze River valley and northeast China in the summer of 1998 (Fu et al. 2005). Fig. 2 shows the total precipitation and mean wind vectors at $850 \mathrm{hPa}$ from 11-20 June 1998 of each RCM, the GPCP, the TRMM and the ERA-Interim, respectively. The GPCP, the TRMM and the ERA-Interim showed much better consistency, although some significant differences were still evident at smaller spatial scales (e.g. in the Bay of Bengal and in the tropical eastern Pacific Ocean). The PCC between the GPCP and the TRMM (ERA-Interim) was 0.90 (0.85). All 3 datasets captured the rainfall belts along $20-35^{\circ} \mathrm{N}$, $105-150^{\circ} \mathrm{E}$. The RCMs revealed high consistency in reproducing low-level winds compared to the ERA-Interim. Furthermore, the characteristic clockwise (anti-clockwise) circulation patterns over the west Pacific Ocean, WPO (northeast China and east Mongolia) which indicate anticyclone (cyclone) cells in corresponding regions were well captured by all of the RCMs. Water vapour is transported within south-westerly monsoonal low-level winds. Over the western part of the WPO High, moisture flux convergences result in rainfall belts along the Yangtze River valley, the East China Sea and the south of Japan, and in the Bay of Bengal. When compared to observations, most of the models captured the rainfall distribution. More than $200 \mathrm{~mm}$ of precipitation accumulation was simulated along the rainfall bands, and the calculated PCC ranged from 0.57 to 0.76 . RegCM4 (YSU-RSM) had the best (worst) performance in simulating flooding, and was able (not able) to simulate rainfall bands accurately. The MME improved both the precipitation (PCC: 0.84) and the low-level wind patterns, when compared to all RCMs, with a significant reduction in bias. 

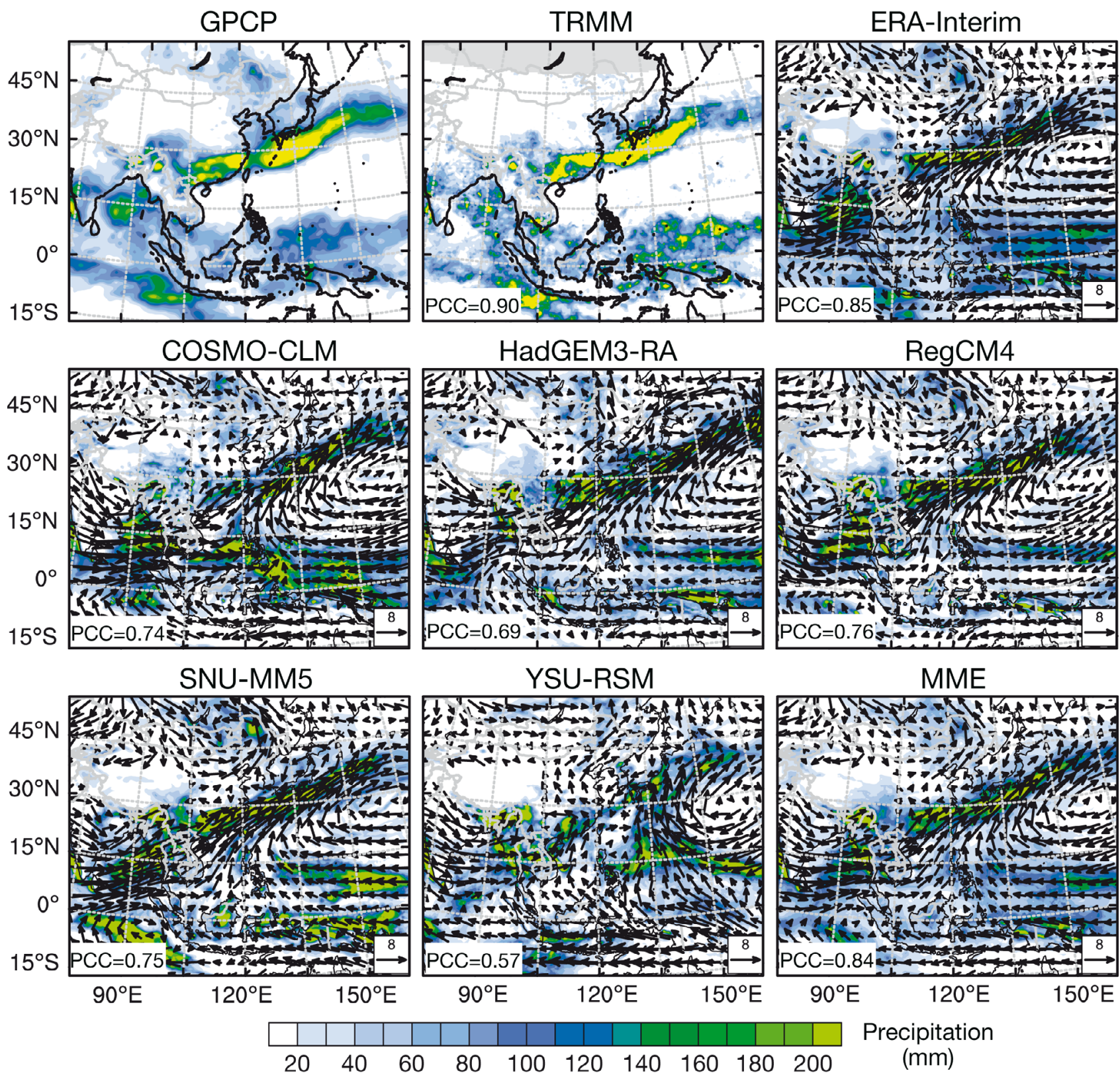

Fig. 2. Total precipitation and wind vectors at $850 \mathrm{hPa}\left(\mathrm{m} \mathrm{s}^{-1}\right)$ over the period 11-20 June 1998. The numbers in the lower/ bottom left-hand corners show the pattern correlation coefficient (PCC) between the observed and simulated rainfall patterns (CORDEX-East Asia). MME: multi-model mean. Datasets are described in Table 2

\subsection{Seasonality}

In the summer months, the observed rain bands stretch from northern India, the Bay of Bengal, the northern Indo-China peninsula and the south of China (Fig. 3; cf. GPCP). Meanwhile, the intertropical convergence zone (ITCZ) reaches its northernmost location (not shown). The TRMM showed strong agreement with the GPCP in the CORDEXEA region, which slightly over- (under-) estimated precipitation in the tropics (sub-tropics). A significant difference occurred at the western Tibetan Plateau and the western Indo-China peninsula (Fig. 3; cf. TRMM). The ERA-Interim revealed similar summer rainfall patterns as the GPCP, but significantly over(under-) estimated precipitation in the equatorial Pacific Ocean and western China (south of Japan, Korean peninsula, and Pacific Ocean at $35-50^{\circ} \mathrm{N}$, $155-170^{\circ} \mathrm{E}_{\text {; Fig. }}$ ). Fig. 3 illustrates the gauge-based precipitation datasets and the GPCP demonstrating 

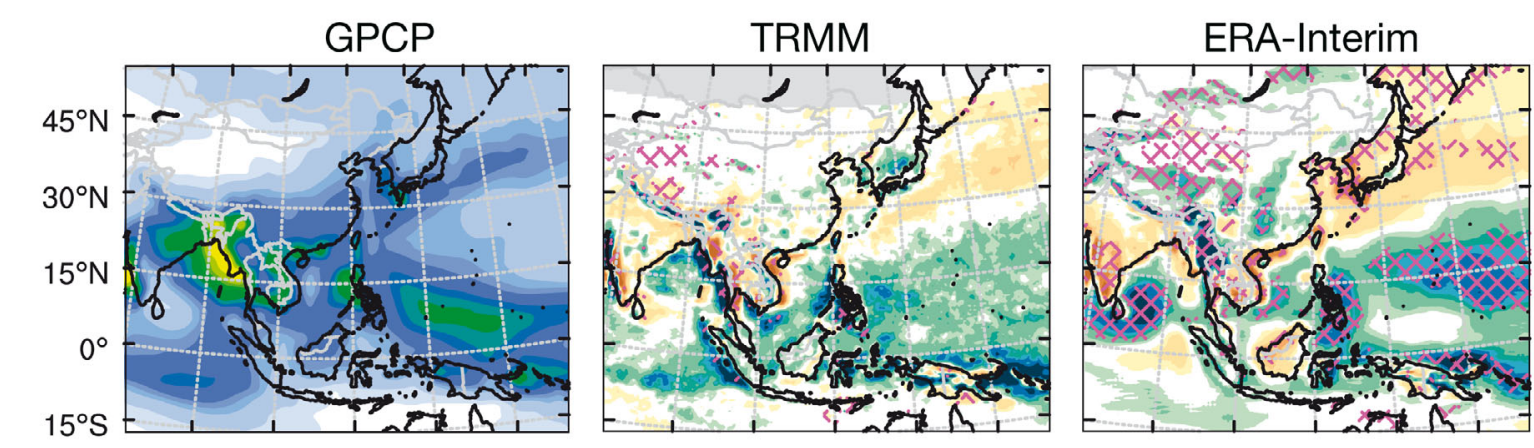

GPCP
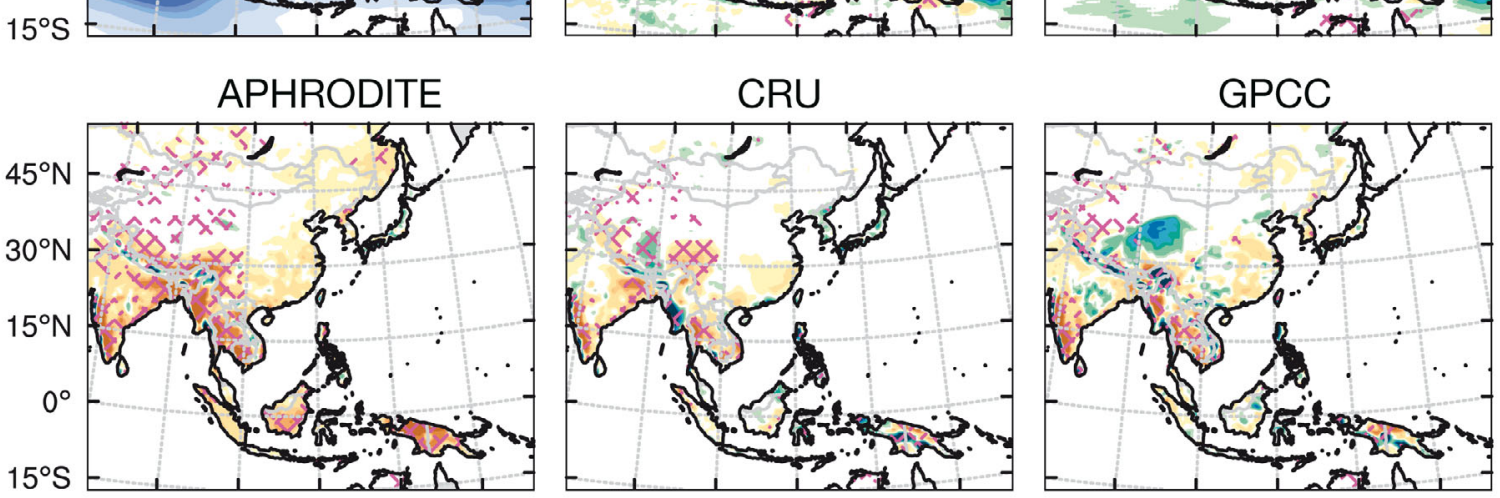

$\left(\mathrm{mm} \mathrm{d}^{-1}\right)$
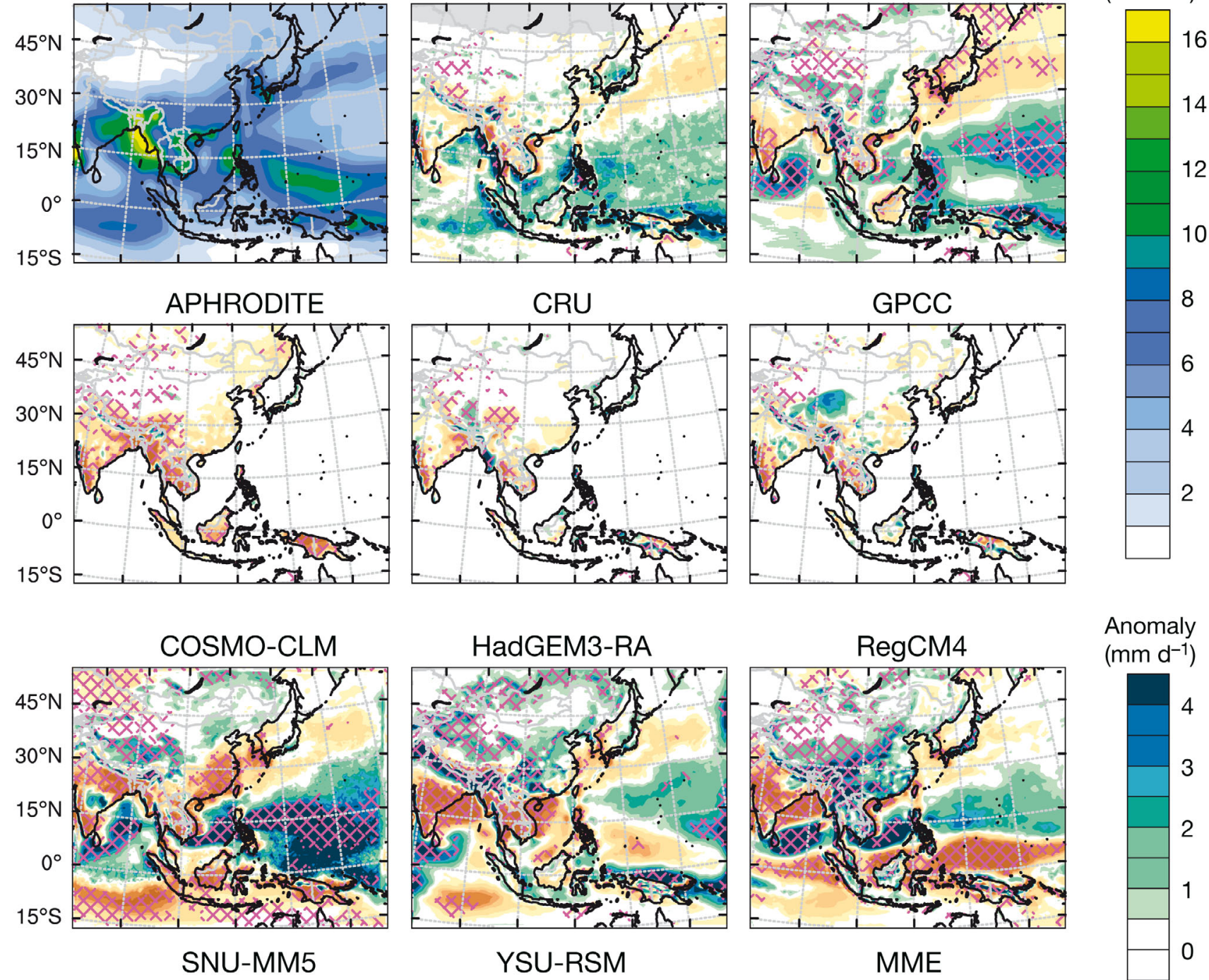

Anomaly

$\left(\mathrm{mm} \mathrm{d}^{-1}\right)$
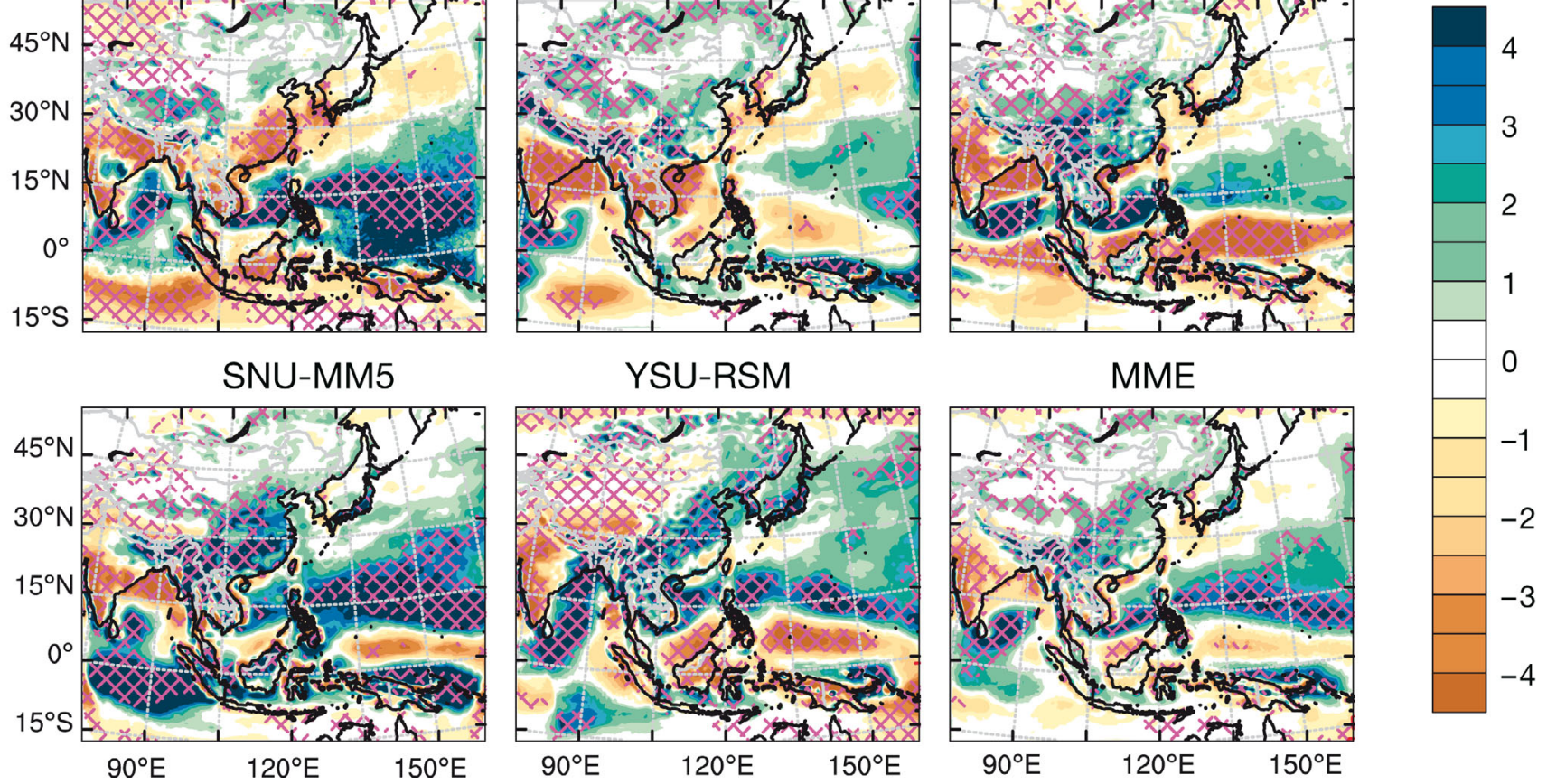

Fig. 3. Summer (JJA) rainfall of the Global Precipitation Climatology Project (GPCP) and the rainfall anomalies 'observation minus GPCP', and 'model minus GPCP' from 1989-2008. The magenta angled grids illustrate the significance level at 0.001. MME: multi-model ensemble mean. Datasets are described in Table 2

much better consistency, although some significant differences were evident at smaller spatial scales (e.g. in southern India, the western Indo-China peninsula and the western Tibetan Plateau). RCMs performed well over northeast Asia $\left(40-50^{\circ} \mathrm{N}, 105-\right.$ $\left.120^{\circ} \mathrm{E}\right)$ and the northwest Pacific Ocean $\left(30-50^{\circ} \mathrm{N}\right.$, $\left.140-165^{\circ} \mathrm{E}\right)$, in which the absolute model bias was $<1 \mathrm{~mm} \mathrm{~d}^{-1}$ compared to the observations (Fig. 3). RCMs simulated a drier Indian sub-continent, except the COSMO-CLM, which reproduced a slight wetter 
central India. The COSMO-CLM, the HadGEM3-RA, the RegCM4 and the SNU-MM5 tended to over-estimate the precipitation over the Tibetan Plateau, especially in the Himalayas $\left(>4 \mathrm{~mm} \mathrm{~d}^{-1}\right)$, where the YSU-RSM simulated less precipitation $\left(\sim 3 \mathrm{~mm} \mathrm{~d}^{-1}\right)$. COSMO-CLM and HadGEM3-RA (RegCM4, SNUMM5 and YSU-RSM) exhibited negative (positive) bias over the Indo-China peninsula. In Indonesia and Malaysia, the SNU-MM5 calculated wetter condi- tions $\left(>4 \mathrm{~mm} \mathrm{~d}^{-1}\right)$, while the other models simulated drier conditions.

In winter, the rain bands withdraw to the south with maximum precipitation $\left(>16 \mathrm{~mm} \mathrm{~d}^{-1}\right)$ in Indonesia and Malaysia (Fig. 4; cf. GPCP). The TRMM showed a good agreement with the GPCP, which had a significant negative bias over the northern Pacific (Fig. 4). The ERA-Interim and the gauge-based precipitation datasets had the same winter precipitation
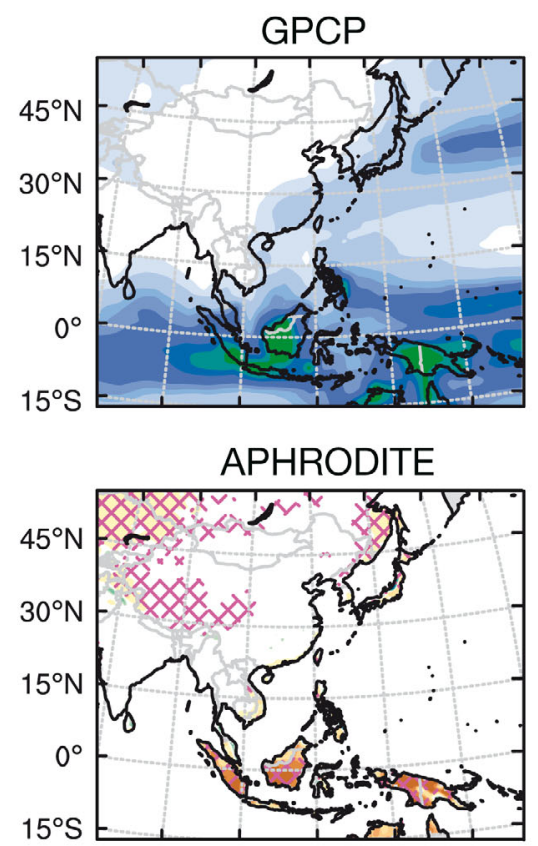

COSMO-CLM

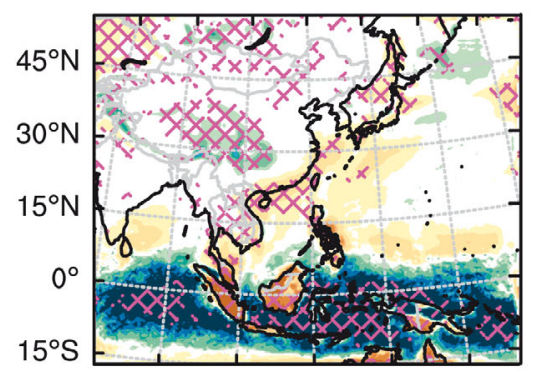

SNU-MM5

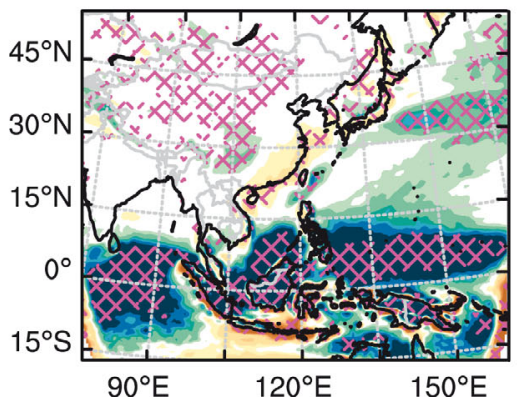

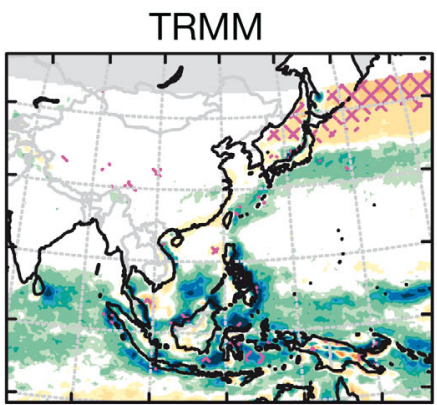

CRU

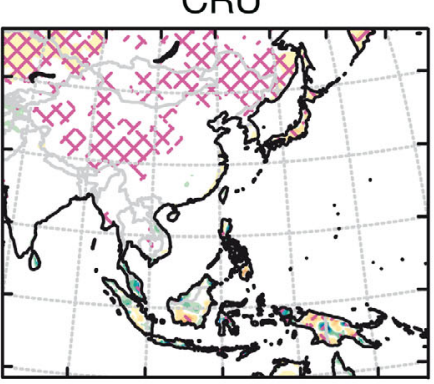

HadGEM3-RA

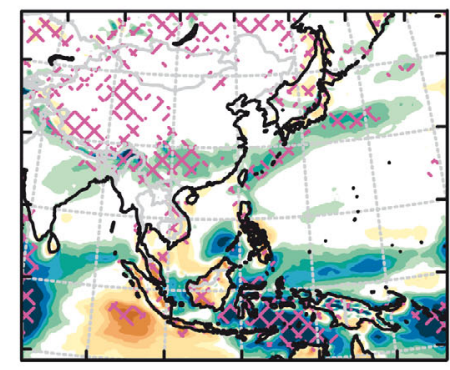

YSU-RSM

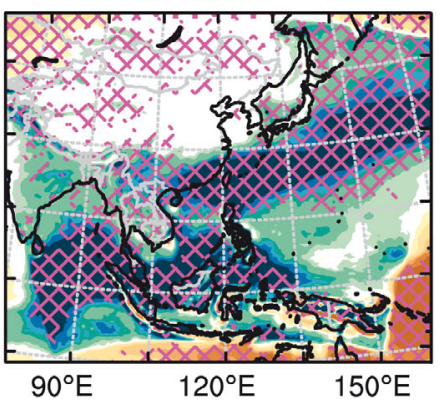

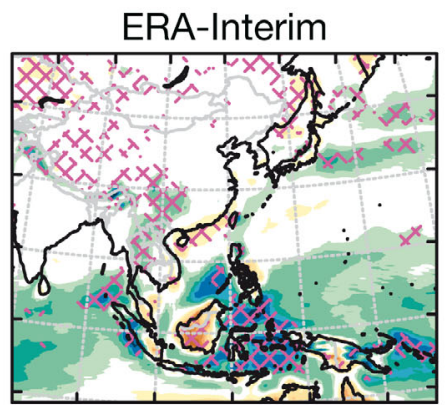

GPCC

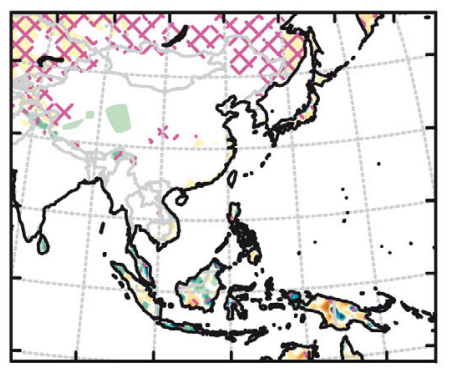

GPCP

$\left(\mathrm{mm} \mathrm{d}^{-1}\right)$

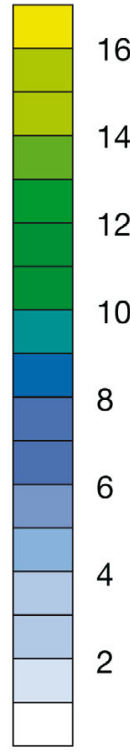

6

4

2

Anomaly $\left(\mathrm{mm} \mathrm{d}^{-1}\right)$

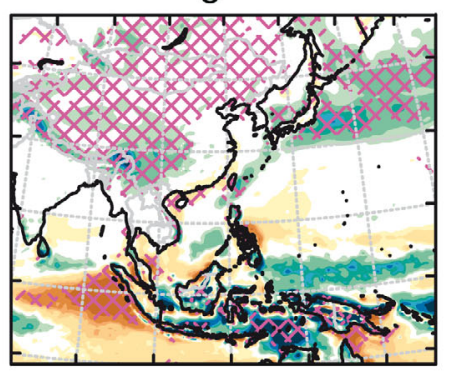

MME

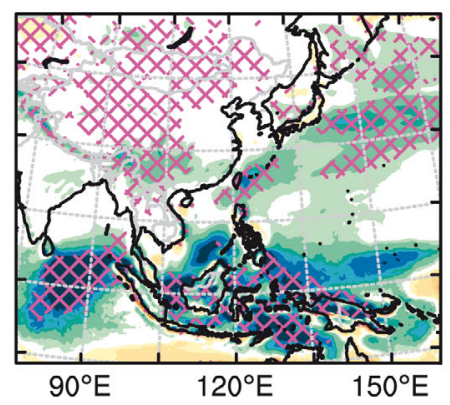

Fig. 4. As in Fig. 3, but for the winter months (DJF) 
Table 3. BIAS $\left(\mathrm{mm} \mathrm{d}^{-1}\right)$, root mean square error (RMSE, $\mathrm{mm} \mathrm{d}^{-1}$ ) and pattern correlation coefficient (PCC) between the simulated precipitation and the observation (Global Precipitation Climatology Project, GPCP) for JJA and DJF over the 4 sub-monsoon domains (SAS: South Asian Summer Monsoon, EAS: East Asian Summer Monsoon, WNP: Western North Pacific Tropical Monsoon, AUSMC: AustralianMaritime Continent Monsoon). MME: multi-model mean. Datasets are described in Table $2 .{ }^{*} \mathrm{p}<0.01 ;{ }^{* *} \mathrm{p}<0.001$

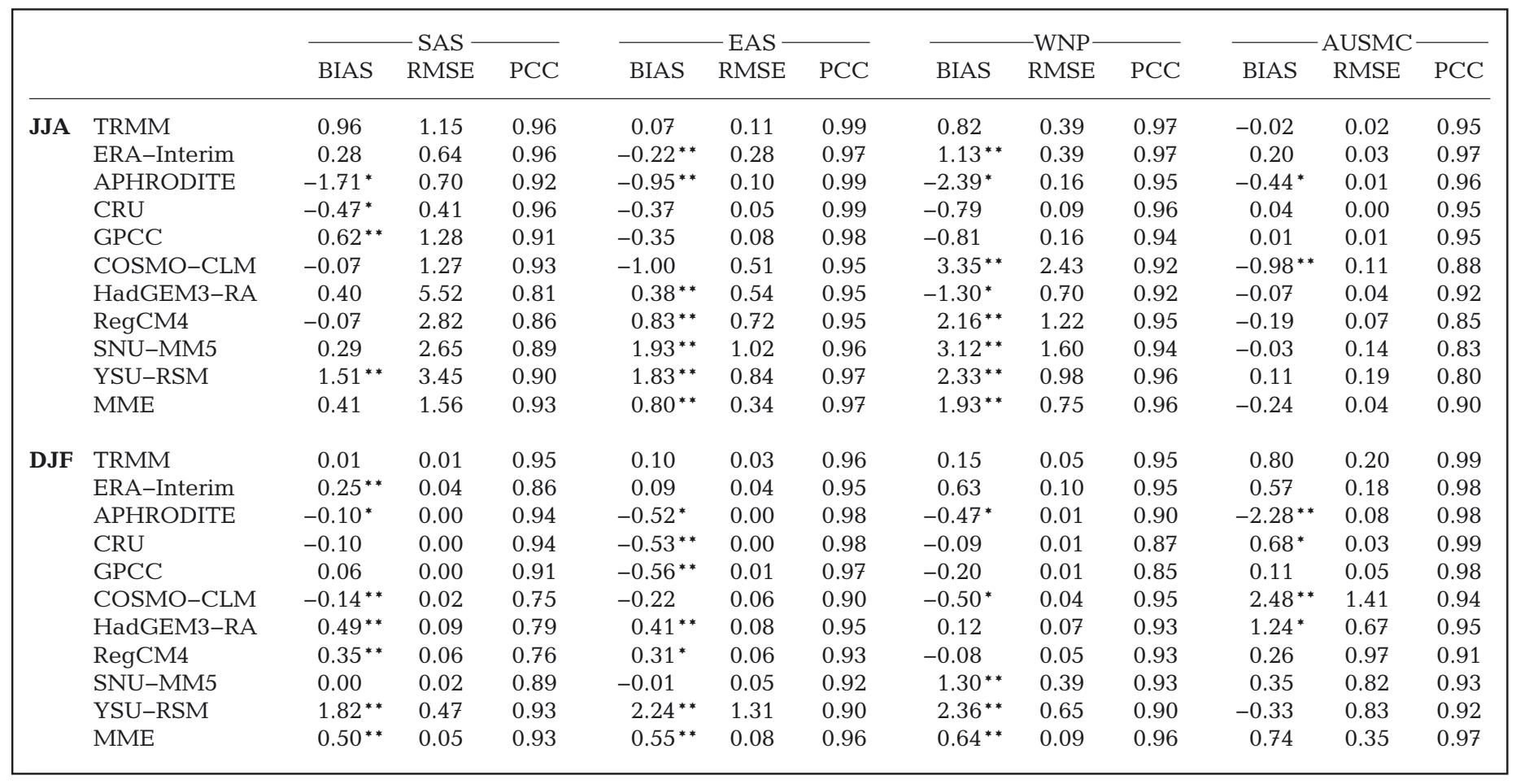

pattern as the GPCP. Significant negative biases $\left(<1 \mathrm{~mm} \mathrm{~d}^{-1}\right)$ occurred over central Asia and eastern Siberia. The RCMs had a tendency to simulate wetter conditions in most parts of the CORDEX-EA domain (Fig. 4). RCMs tended to over-estimate winter precipitation $\left(\sim 1 \mathrm{~mm} \mathrm{~d}^{-1}\right)$ in the Tibetan Plateau and the equatorial ocean, while they tended to underestimate it over central Asia. In south China and the South China Sea, the RCM biases showed opposite signs among the individual simulations, where the YSU-RSM (COSMO-CLM) simulated a significantly wetter (drier) bias while the other 3 models had a non-significant bias. We found that the YSU-RSM modelled too much precipitation over the Pacific Ocean at $20-40^{\circ} \mathrm{N}, 120-165^{\circ} \mathrm{E}$.

The statistical evaluation of model performance in simulating the spatial precipitation patterns over 4 sub-monsoon domains during the present (19892008) climate period are presented in Table 3 . For the summer season, the TRMM showed good agreement with the GPCP over the 4 sub-monsoon domains, while the ERA-Interim significantly under-(over-) estimated precipitation in the EAS (WNP). Compared to the GPCP, APHRODITE had a significant dry bias, while the CRU and the GPCC showed consistency.
The RCMs tended to simulate more precipitation in the SAS, the EAS and the WNP, but less precipitation in the AUSMC. In the SAS, the bias ranged from -0.07 to $1.51 \mathrm{~mm} \mathrm{~d}^{-1}$, but only the YSU-RSM simulated a significant wetter condition $\left(1.51 \mathrm{~mm} \mathrm{~d}^{-1}\right)$. The COSMO-CLM (BIAS: $-1.00 \mathrm{~mm} \mathrm{~d}^{-1}$ ) simulated a drier EAS, while the other $4 \mathrm{RCMs}$ were wetter, with a BIAS ranging from 0.38 to $1.93 \mathrm{~mm} \mathrm{~d}^{-1}$. As in the EAS, the RCMs had a tendency to simulate more precipitation in the WNP, except the HadGEM3-RA (BIAS: $-1.30 \mathrm{~mm} \mathrm{~d}^{-1}$ ). RCMs slightly under-estimated the JJA rainfall in the AUSMC where the COSMOCLM simulated the wettest condition (BIAS: $0.98 \mathrm{~mm}$ $\mathrm{d}^{-1}$ ). Furthermore, the RCMs showed higher RMSEs $\left(1.28-5.50 \mathrm{~mm} \mathrm{~d}^{-1}\right)$ in the SAS and lower RMSEs (0.03-0.19 $\mathrm{mm} \mathrm{d}^{-1}$ ) in the AUSMC. The RCMs captured summer precipitation patterns better in the EAS (PCC: 0.95-0.97) than in the other 3 regions. In the winter season, the TRMM and the ERA-Interim showed good agreement with the GPCP. The regridded gauge datasets slightly under-estimated the precipitation in the 4 sub-monsoon regions, especially in the EAS (BIAS: $-0.52,-0.53,-0.56 \mathrm{~mm} \mathrm{~d}^{-1}$, respectively). APHRODITE had a significant negative bias for the DJF rainfall in the CORDEX-EA. 
When compared to the summer season, the RCMs tended to over-estimate the winter precipitation in the 4 sub-monsoon regions, except in the AUSMC. The COSMO-CLM simulated a noticeable dry bias in the SAS and the WNP, whereas the other RCMs presented a significant wet bias. The RMSEs (0.68$\left.1.43 \mathrm{~mm} \mathrm{~d}^{-1}\right)$ in the AUSMC were larger than in the SAS $\left(<0.47 \mathrm{~mm} \mathrm{~d}^{-1}\right)$, EAS $\left(<1.28 \mathrm{~mm} \mathrm{~d}^{-1}\right)$ and WNP $\left(<0.64 \mathrm{~mm} \mathrm{~d}^{-1}\right)$.

In both seasons, the MME captured the precipitation patterns better than the individual models, leading to the highest PCC and lower BIAS and RMSE (Table 3). In JJA, the precipitation difference between the MME and the observations ranged from -1.0 to $1.0 \mathrm{~mm} \mathrm{~d}^{-1}$ in most parts of the CORDEX-EA (Fig. 3). A significant positive (negative) bias oc- curred in the Pacific Ocean at $5-15^{\circ} \mathrm{N}, 135-165^{\circ} \mathrm{E}$ (the Indian sub-continent). For DJF, the MME showed wetter conditions than the GPCP (e.g. in central China, Mongolia and the Pacific Ocean at 28$\left.55^{\circ} \mathrm{N}, 140-165^{\circ} \mathrm{E}\right)$, especially in the equatorial area (>3 $\mathrm{mm} \mathrm{d}^{-1}$; Fig. 4). The bias between the MME and the GPCP was significant in the EAS and in the WNP for JJA, and in the SAS, EAS and WNP for DJF, respectively (Table 3).

\subsection{Annual cycle}

Fig. 5 illustrates the mean annual cycle of precipitation averaged over 4 sub-monsoon regions as presented in Fig. 1. The annual cycle depicts the promi-
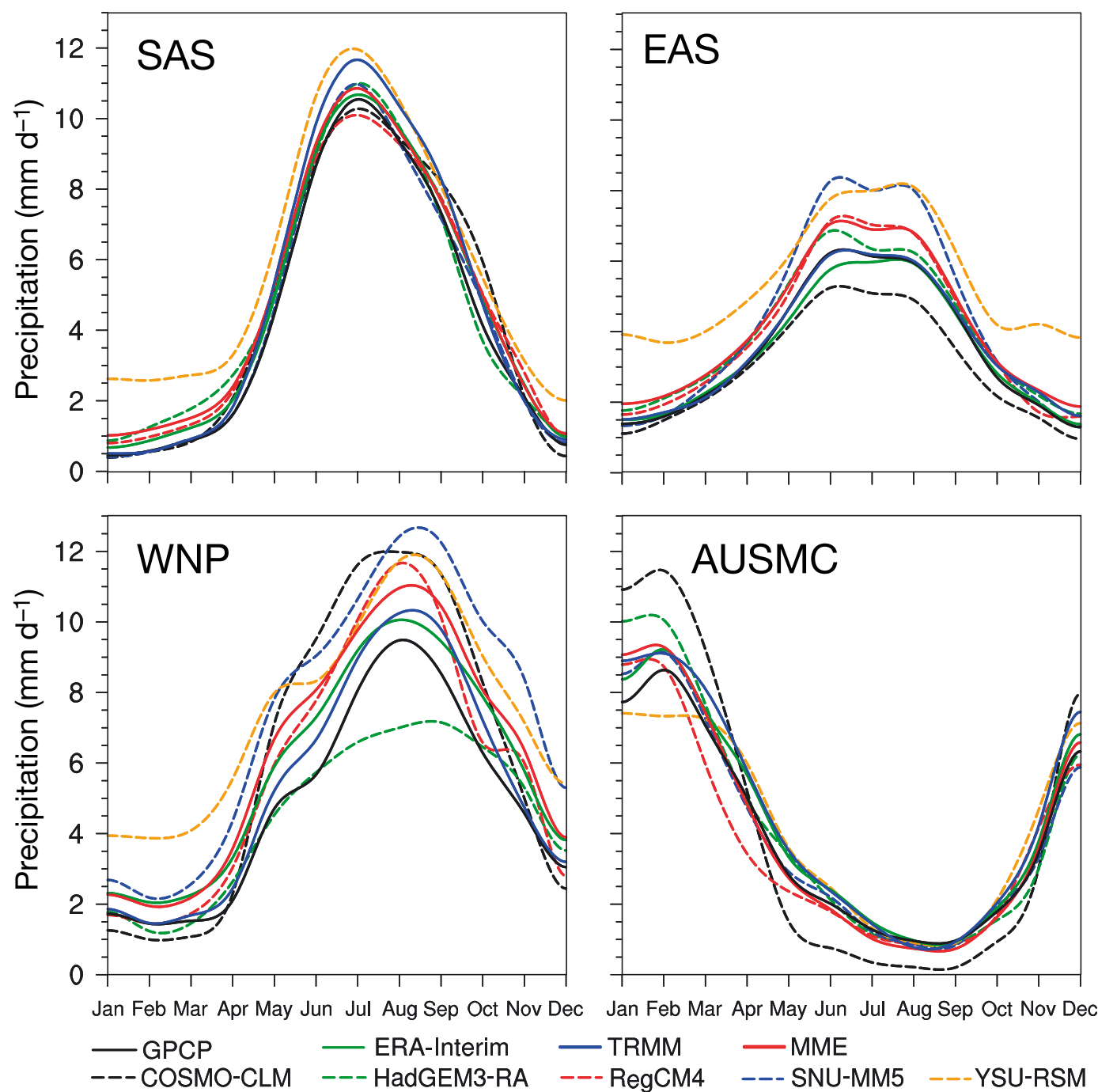

Fig. 5. Annual cycle of monthly precipitation averaged over the 4 sub-monsoon domains for the period 1989-2008 for the Global Precipitation Climatology Project (GPCP, solid black line), the ERA-Interim (solid green line), TRMM (solid blue line), each of the regional climate models (RCMs, coloured dashed lines) and their multi-model ensemble mean (MME, solid red line). Datasets are described in Table 2 
nent features of the precipitation in this region associated with the summer monsoon: dry conditions in the boreal winter and a rainy season from May to September (November to March) in the northern (southern) hemisphere. The ERA-Interim and the TRMM were consistent with the GPCP in the EAS and the AUSMC, and slightly over-estimated the peak in the SAS and the WNP. In general, they were much closer to the GPCP during the summer monsoon season of each monsoon system.

In the SAS, most of the RCMs were in close agreement with the observations; only the YSU-RSM simulated a slightly wetter $\left(<1 \mathrm{~mm} \mathrm{~d}^{-1}\right)$ summer and winter. In the EAS, the RCMs simulated 2 peaks in June and August. Furthermore, the RCMs demonstrated a large range in simulating summer precipitation and a small amplitude in the pre-monsoon and post-monsoon seasons. The COSMO-CLM identified a negative bias, while other models tended to show a positive bias, especially in the summer. The YSU-RSM simulated a much wetter winter $\left(2 \mathrm{~mm} \mathrm{~d}^{-1}\right)$ and summer. Over the WNP, most of the RCMs indicated an earlier onset of the rainy season (May) compared to observations (June) and indicated that it is much wetter throughout the year. As in the EAS, the YSURSM showed a much wetter winter $\left(2 \mathrm{~mm} \mathrm{~d}^{-1}\right)$ and summer. The HadGEM3-RA calculated a consistent onset of the rainy season, but failed to simulate the maximum and the withdrawal of the monsoon. In the AUSMC, the models demonstrated the annual cycle well, and only the YSU-RSM failed to exhibit the

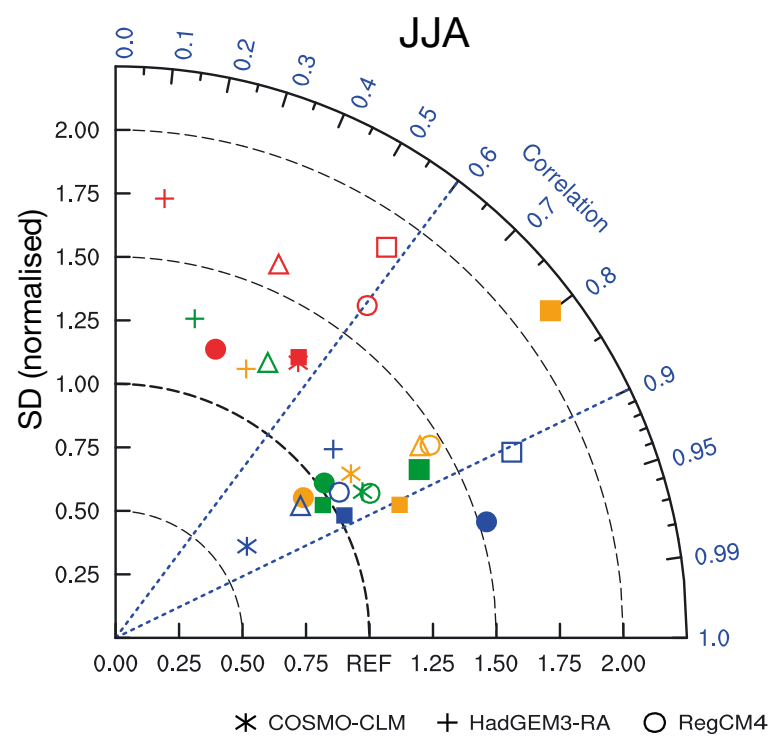

peak of the summer rainfall (January-March), while the HadGEM3-RA and the COSMO-CLM both overestimated the rainy season rainfall.

The MME was closer to the observed annual cycle than the individual models. The RCMs performed better in simulating the annual cycle in the SAS and the AUSMC than in the EAS and the WNP.

\subsection{Inter-annual variability}

The temporal statistics describing inter-annual variability of the JJA and the DJF mean precipitation averaged over the 4 sub-monsoon domains are shown in Fig. 6 for the ERA-Interim, each of the RCM members and the MME compared to the GPCP. For JJA, the inter-annual variability of precipitation was less prominent over the SAS. The ERA-Interim calculated a low correlation coefficient (0.33) with the GPCP. The majority of the RCMs failed to reproduce the year-to-year variation in the precipitation with a relatively low correlation coefficient. We note that the RegCM4 showed a better performance in representing the inter-annual variation in rainfall, with a higher correlation coefficient of 0.60 and medium normalised standard deviations of 1.64. For the HadGEM3-RA, we calculated the lowest correlation coefficient (0.11). The GPCP and the ERA-Interim showed a strong correspondence in the sign and magnitude of the interannual variability in the EAS with a high correlation coefficient of 0.81 . The RCMs exhibited a lesser dis-

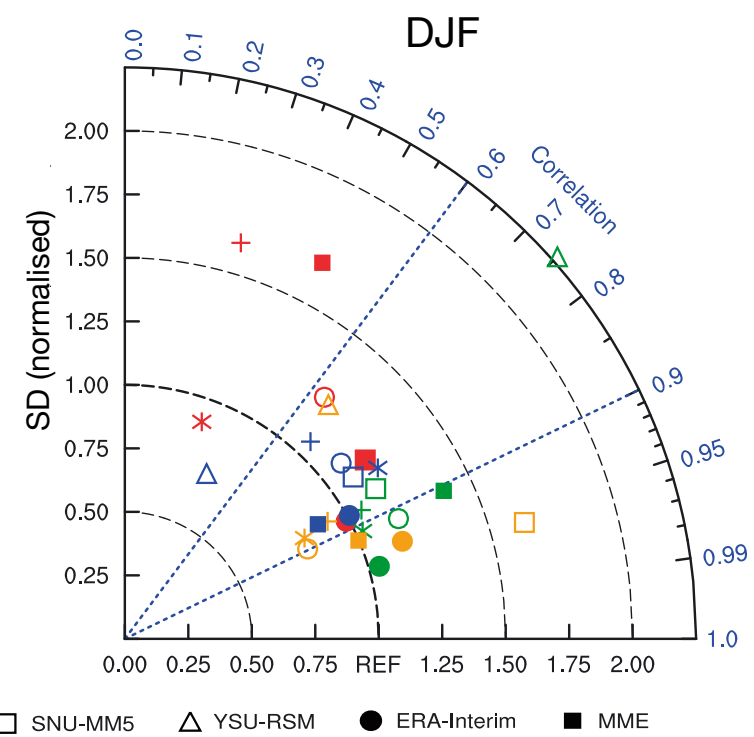

Fig. 6. Temporal statistics describing inter-annual variability of the models in terms of the JJA and the DJF mean precipitation, the multi-model ensemble mean (MME) and the ERA-Interim compared with the Global Precipitation Climatology Project (GPCP) over the South Asian Summer Monsoon (red), the East Asian Summer Monsoon (green), the Western North Pacific

Tropical Monsoon (orange) and the Australian-Maritime Continent Monsoon (blue). Datasets are described in Table 2 
crepancy to the observations, with a generally higher correlation coefficient in the EAS compared to the SAS. The HadGEM3-RA and the YSU-RSM had a worse performance in capturing the inter-annual variability compared to the other models. In the WNP, the RCMs exhibited a wide spread (ranging from 4 to $8 \mathrm{~mm} \mathrm{~d}^{-1}$ ) in simulating precipitation. The models almost failed to show the inter-annual variability; especially in the 2000s, the RCMs showed different phases to the observations (not shown). The best performance was shown in the RegCM4 (correlation coefficient: 0.72). Compared to the GPCP, the RCMs captured the sign and magnitude of the interannual variability well. In the AUSMC, for the majority of the RCMs, the correlation coefficient was above 0.76 , while the correlation of the SNU-MM5 was much higher (0.91).

As in the summer season, RCMs illustrated insufficient performance in representing the inter-annual variability of winter precipitation over the SAS (Fig. 6; cf. DJF). The RCMs exhibited good performance in capturing year-to-year variation in winter precipitation over the EAS, the WNP and the AUSMC, with closer agreement of inter-annual rainfall variability and a higher correlation coefficient compared to the GPCP. The ERA-Interim showed a close correspondence in reproducing the sign and magnitude of winter precipitation to the GPCP over the 4 regions. The SNU-MM5 exhibited the best performance in capturing the inter-annual variability in winter precipitation with a higher correlation coefficient $(>0.80)$ and closer year-to-year variation $(\sim 1.10)$ than the GPCP over the 4 sub-monsoon regions. We found that the YSU-RSM significantly over-estimated the winter precipitation $\left(>2 \mathrm{~mm} \mathrm{~d}^{-1}\right.$ ) compared to the observation in the SAS, EAS and WNP. In addition, The YSU-RSM calculated the lowest correlation coefficient compared to the other 4 models, especially in the SAS.

In the summer and winter seasons, the MME clearly improved the overall variability of most RCMs in the 4 regions, with a smaller bias and higher correlation coefficient, in the SAS (0.55 and 0.46), EAS (0.84 and 0.91), WNP (0.91 and 0.92) and AUSMC (0.88 and 0.86) for JJA and DJF, respectively. Note that the MME showed a larger difference in winter precipitation than the ERA-Interim and several of the RCMs in the SAS.

\subsection{Monsoon characteristics}

Compared to the GPCP, the merged observation (APHRODITE, CRU and GPCC; PCC: 0. 98, NRMSE:
0.21) had small negative biases $\left(-1 \mathrm{~mm} \mathrm{~d}^{-1}\right)$ of the annual mean precipitation over western India and central China, whereas small positive biases occurred over the Himalayas (Fig. $7 \mathrm{a}$; cf. Observation). The MME was able to reproduce the observed spatial distribution features of the annual mean precipitation as well as the major tropical convergence zones over the ocean and the main rainfall belts in the extra-tropical Pacific. The differences between the observations and the individual model simulations show that the MME simulated wetter conditions over the equatorial Indian Ocean, the Bay of Bengal, the equatorial western Pacific and the southern Himalayas, but a drier central Asia and Indian subcontinent (Fig. 7a). Furthermore, over the tropics, the HadGEM3-RA simulated more accurate precipitation patterns, while the COSMO-CLM, the SNUMM5 and the YSU-RSM showed wetter conditions, and the RegCM4 drier conditions (not shown). The PCC of the individual models varied from 0.91 to 0.95 , and the NRMSE varied from 0.66 to 1.19 . Compared to other RCMs, the HadGEM3-RA (SNU-MM5) had a better (worse) performance (NRSME: 0.66 [1.19]) in reproducing spatio-temporal patterns of annual mean precipitation. The MME was significantly better than the individual models in simulating annual mean precipitation with a PCC of 0.98 and an NRMSE of 0.61 (Fig. 8).

The first annual cycle mode (AC1, summer-winter asymmetric mode) is the difference in precipitation between June-September (JJAS) and DecemberMarch (DJFM), while the second annual cycle mode (AC2, spring-fall asymmetric mode) is the difference between April-May (AM) and October-November (ON) (Wang \& Ding 2008, Lee \& Wang 2014). Compared to the GPCP, the Observation represents the first and the second annual cycle mode with a high degree of accuracy. The MME tended to overestimate the magnitude of the AC1 over the extratropical Pacific Ocean and under-estimated it over the East China Sea (Fig. 7b). The model simulations can reproduce the observed AC1 realistically with PCCs ranging from 0.71 to 0.83 and NRMSEs ranging from 0.74 to 1.07 , respectively (Fig. 8). However, the SNU-MM5 simulated a stronger AC1 over both the NWP and the EAS (not shown). At the same time, the SNU-MM5 performed poorly (PCC: 0.71, NRMSE: 0.99) in representing the AC1. Furthermore, the model simulations had difficulties capturing the $\mathrm{AC} 2$, as the model spread for this mode was much larger. The PCCs varied from 0.72 to 0.81 and the NRMSEs varied from 0.73 to 1.22 , respectively (Fig. 8). The MME performed well and showed the 
GPCP

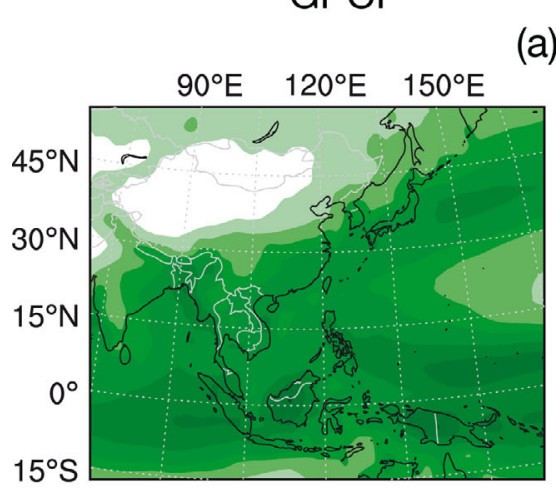

Observation

(a) Annual mean precipitation

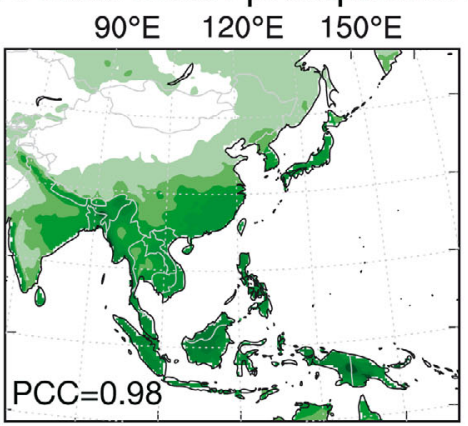

\section{MME}

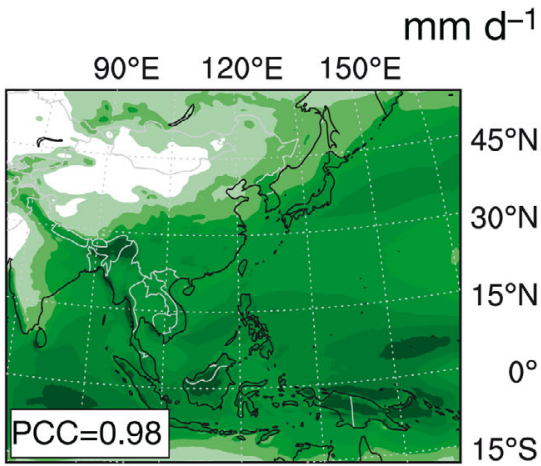

(b) The first annual cycle (JJAS minus DJFM)

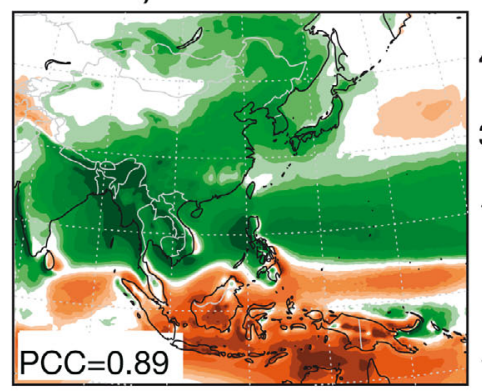

$\mathrm{mm} \mathrm{d}^{-1}$

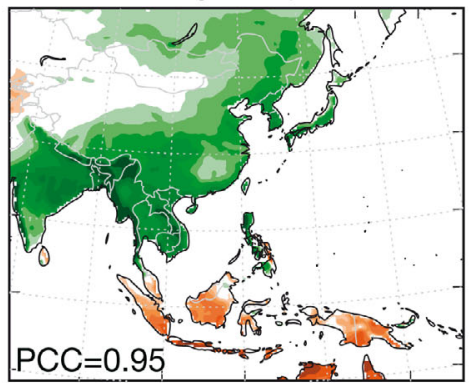

$\mathrm{PCC}=0.89$

$\mathrm{PCC}=0.95$ 2and

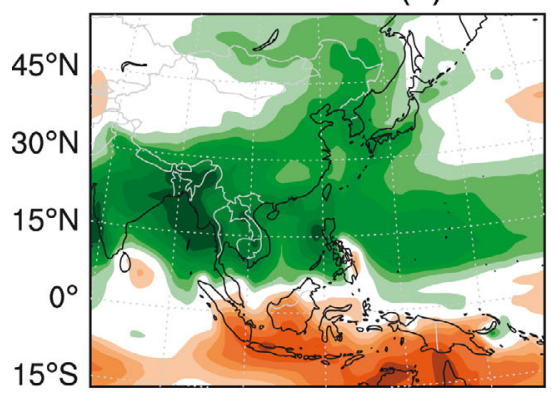

(c) The second annual cycle (AM minus ON)
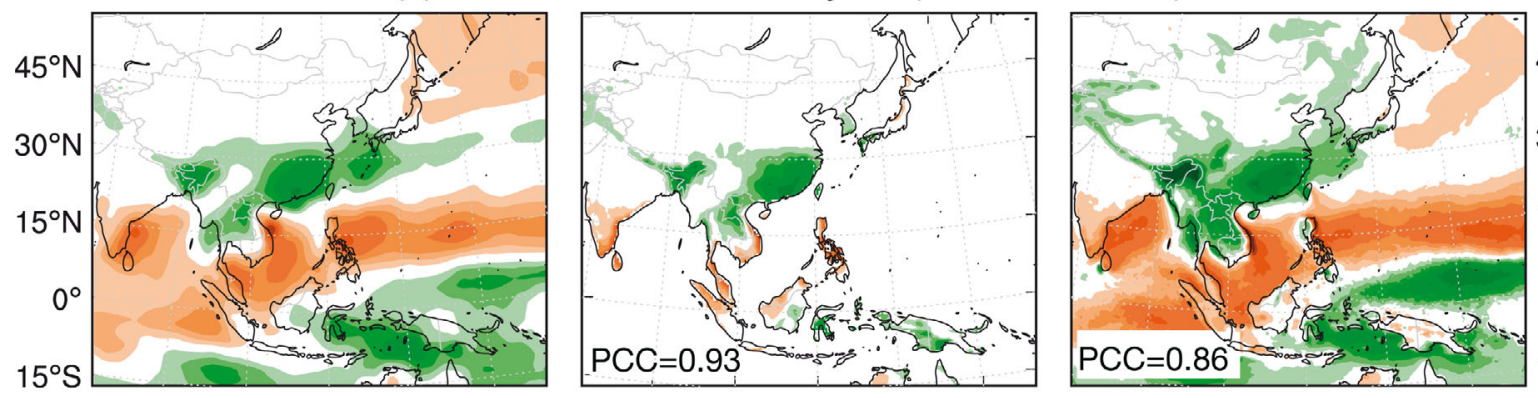

$45^{\circ} \mathrm{N}$

$30^{\circ} \mathrm{N}$

$15^{\circ} \mathrm{N}$

$0^{\circ}$

$15^{\circ} \mathrm{S}$

(d) Monsoon precipitation intensity and domain
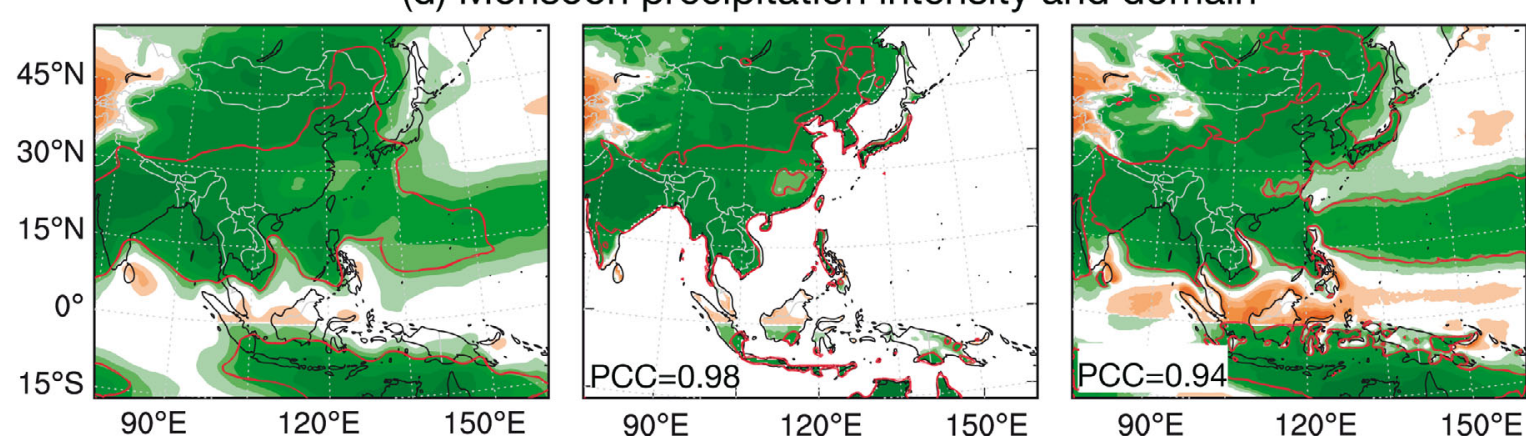

$\times 0.1$ $45^{\circ} \mathrm{N}$

$30^{\circ} \mathrm{N}$

$15^{\circ} \mathrm{N}$

$0^{\circ}$

$15^{\circ} \mathrm{S}$

Fig. 7. Comparison of the precipitation climatology (1989-2008) between the Global Precipitation Climatology Project (GPCP), the merged observation (APHRODITE, CRU, GPCC; datasets are described in Table 2) and the multi-model ensemble mean (MME): (a) annual precipitation rate $\left(\mathrm{mm} \mathrm{d}^{-1}\right)_{;}(\mathrm{b})$ the first annual cycle mode (AC1, June-September minus December-March); (c) the second annual cycle mode (AC2, April-May minus October-November); and (d) monsoon precipitation intensity (non-dimensional) and domain. The numbers in the bottom left-hand corners show the pattern correlation coefficient (PCC) between the observed and the simulated patterns (CORDEX-East Asia) 


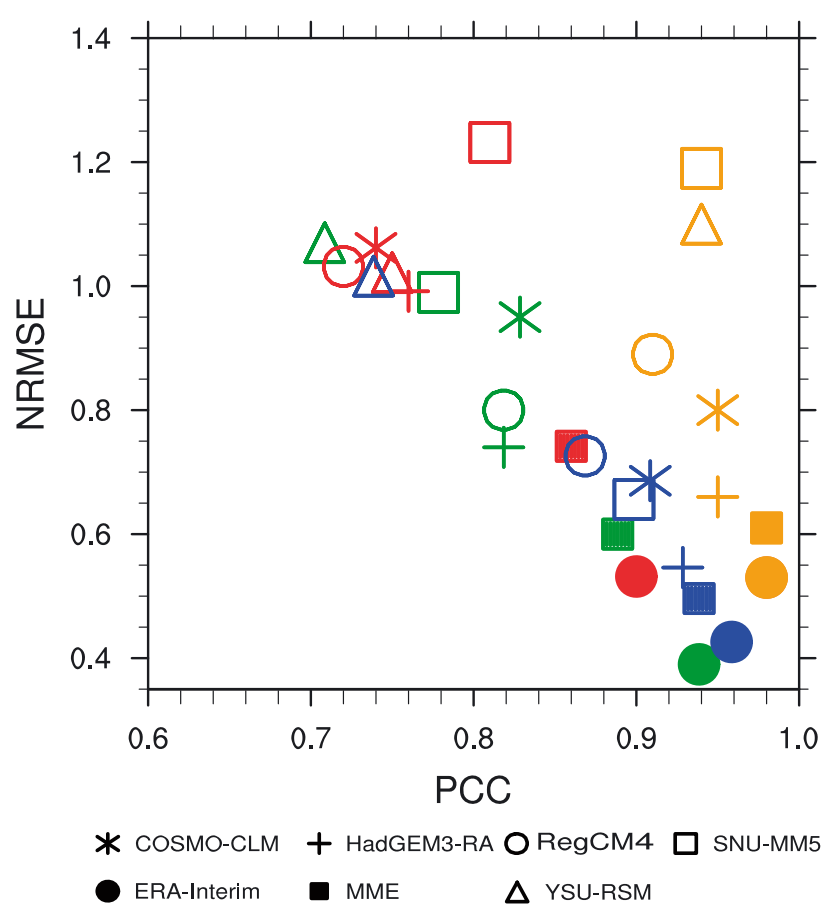

Fig. 8. Performance of the regional climate models and their multi-model ensemble means (MMEs) on precipitation climatology (1989-2008): the annual mean precipitation (orange), the first annual cycle mode (June-September minus December-March; green), the second annual cycle mode (April-May minus October-November; red), and the monsoon precipitation intensity (the ratio of 'summer minus winter' to annual total precipitation; blue). The abscissa and ordinates are pattern correlation coefficient (PCC) and domain-averaged root mean square error normalised by the observed spatial standard deviation (NRMSE), respectively. The observed precipitation data are from the Global Precipitation Climatology Project. Datasets are described in Table 2

$\mathrm{AC} 1$ and AC2 better than the individual models did, and it was more effective for the AC1 than the AC2. The MME's PCC was 0.89 (0.86) and its NRMSE was 0.60 (0.73) for the AC1 (AC2), averaged over the CORDEX East Asia region.

Wang et al. (2011) defined the monsoon precipitation intensity (MPI) as the ratio of 'summer minus winter' compared to annual total precipitation, and the monsoon domain as the regions where the 'summer minus winter' precipitation exceeds $2.5 \mathrm{~mm} \mathrm{~d}^{-1}$ and the summer precipitation exceeds $55 \%$ of the annual total. Compared to the GPCP, the Observation captured the MPI and monsoon domain over land well, with a PCC of 0.98 and an NRMSE of 0.43 . The individual models showed good performance in representing the MPI pattern, with PCCs ranging from 0.74 to 0.93 and NRMSEs ranging from 0.55 to 1.02 (Fig. 8). The YSM-RSM had the worst perform- ance in simulating the MPI, with the lowest PCC (0.74) and NRMSE (1.02), and the MPI was significantly under-estimated. The HadGEM3-RA showed the best agreement in the MPI (PCC: 0.93, NRMSE: 0.55) and the monsoon domain compared to the GPCP. The MME exhibited an eastern extension of the WNP domain towards the middle Pacific and a northern extension of the EAS domain towards eastern Siberia, while it failed to show the monsoon domain over the East China Sea. Similar to the other 3 metrics, the MME improved the performance to reproduce the MPI when compared to the individual models with a higher PCC (0.94) and a lower NRMSE (0.50).

\section{DISCUSSION AND SUMMARY}

We presented a first evaluation of the precipitation climatology based upon an ensemble of RCM simulations performed within the CORDEX-EA project. In this regard, 5 different RCMs, driven by the ERAInterim, were run at $\sim 50 \mathrm{~km}$ horizontal resolution over the period from 1989-2008. We examined the performance of the individual models and the ensemble mean in reproducing present-day interannual variability, annual cycles and seasonal mean precipitation as well as monsoon characteristics. Gridded monthly precipitation datasets (i.e. the GPCP and the ERA-Interim) were used as comparison data to evaluate the model performances.

The RCMs from the CORDEX-EA were able to capture the pronounced extreme rainfall event observed from 11-20 June 1998 (Fig. 2), which could not be reproduced well in earlier RCM studies (e.g. RMIP Asia; Fu et al. 2005). Models from RMIP Asia tend to over-estimate precipitation at high latitudes (Fu et al. 2005) and fail to reproduce the heavy rainfall belts along the Yangtze River valley, the East China Sea and southern Japan. This difference in performance might be due to a new RCM generation (i.e. RegCM4) used for the CORDEX-EA with better physical parameterization compared to the RCMs (i.e. RegCM2) from RMIP Asia (Giorgi et al. 2012). Furthermore, the SNU-MM5 also contributed to the RMIP (named SNU RCM). The SNU-MM5 and the SNU RCM have the same physical package, but a different convection scheme, viz. Kain-Fritsch and Grell, respectively. The SNU-MM5 showed a better performance in capturing the extreme rainfall event than the SNU RCM from RMIP. The Kain-Fritsch convection scheme is able to better capture the extreme rainfall than the Grell in SNU-MM5/SNU RCM. 
In general, most of the CORDEX-EA RCMs captured the main features of the seasonal mean rainfall patterns (Figs. $3 \& 4$ ), the annual cycles (Fig. 5) and the inter-annual variability (Fig. 6). However, we found significant biases in the individual models depending on both the region and the season. In the summer season, the RCMs tended to over-estimate precipitation over the Tibetan Plateau, with the exception of the YSU-RSM, which simulated a drier Tibetan Plateau. All RCMs simulated a significantly drier Indian sub-continent $\left(>3 \mathrm{~mm} \mathrm{~d}^{-1}\right.$; Fig. 3). For the winter season, the RCMs had a tendency to reproduce a wetter continent. The HadGEM3-RA and the RegCM4 captured precipitation well, while the COSMO-CLM, SNU-MM5 and YSU-RSM were too wet $\left(>4 \mathrm{~mm} \mathrm{~d}^{-1}\right)$ in the tropics (Fig. 4). The RCMs simulated the annual cycle better in the SAS and the AUSMC than in the EAS or the WNP (with less difference from the observation), especially in the summer season (Fig. 5). Furthermore, the models showed the inter-annual variability in precipitation better in the EAS and the AUSMC than in the SAS and the WNP (Fig. 6). The MME generally out-performed many of the individual models, with biases of similar magnitude compared to observational datasets. Similar to earlier findings in multi-model studies (Paeth et al. 2011, Nikulin et al. 2012, Gbobaniyi et al. 2014), the good performance is mostly influenced by the elimination of the opposite-signed biases among the models, e.g. in south China and the Tibetan Plateau.

Compared to the GPCP, all the other observations showed a drier Indian sub-continent and western Indo-China peninsula, and wetter southern slopes of the Himalayas. The possible reason is that the other station based observations have a finer resolution than the GPCP, allowing the capture of local precipitation. Furthermore, the significant bias over the south Himalayas and the Kunlun Mountains is likely a result of the low density of meteorological stations (Yatagai et al. 2009, Wu et al. 2011). Therefore, the bias of the RCMs over small-scale regions is not accurate due to the coarse resolution of the observations (Stephens et al. 2012). In addition, the models substantially differed in simulating monsoon precipitation, indicating that the internal dynamics and physics play an essential role in the RCM performance. The RegCM4 and the SNU-MM5 showed the same pattern in precipitation bias over the continent because they used the same land surface scheme and a similar radiation scheme. However, the RegCM4 and the SNU-MM5 presented a different bias pattern over the ocean (Fig. 3). We conclude that the convection scheme plays an important role in simulating monsoon precipitation, especially over the ocean, which coincides with the findings of Sylla et al. (2011). Furthermore, the RegCM4 and the SNUMM5 have the same dynamic core, but the RegCM4 (SNU-MM5) adapts hydrostatic (non-hydrostatic) primitive equations (Lee et al. 2004, Giorgi et al. 2012). Additionally, the RegCM4 showed better performance in capturing short- to long-term temporal scales of precipitation than the SNU-MM5. The nonhydrostatic model did not outperform the hydrostatic model. It is worth mentioning that HadGEM3-RA does not implement the spectral nudging technique, while the other 4 models do. The HadGEM3-RA exhibited an acceptable performance in capturing the pattern and the annual cycle of precipitation, but a worse performance than the other 4 RCMs in representing the inter-annual variability in precipitation.

The COSMO-CLM and the SNU-MM5 had a significant positive bias over the extra-tropical Pacific $\left(10-20^{\circ} \mathrm{N}, 120-165^{\circ} \mathrm{E}\right)$, but the COSMO-CLM underestimated the summer precipitation over south China while the SNU-MM5 over-estimated it. Hence, the COSMO-CLM and the SNU-MM5 illustrated a compelling discrepancy in the annual cycle over the EAS and the WNP. Moreover, the HadGEM3-RA failed to capture the annual cycle in the WNP (Fig. 5) due to the significant under-estimate of precipitation over the South China Sea (Fig. 3). In SAS, the RCMs showed large discrepancies among one another in simulating seasonal rainfall on an inter-annual time scale because the uncoupled RCMs could not capture the large-scale ocean oscillation (Jiang et al. 2013). In addition, the El Niño-Southern Oscillation (ENSO) provides the most systematic forcing of interannual variability for the Asian monsoon system (Wang et al. 2000, Wang 2006, Annamalai et al. 2007). RCMs exhibited different performance in describing the year-to-year variation in the 4 sub-monsoon regions. In East Asia, the RCMs may have the ability to capture the Pacific-East Asian teleconnection, which is a mechanism that links central Pacific sea surface temperature anomalies with East Asian climate variations (Wang et al. 2000). However, the RCMs showed the worst performance in capturing the inter-annual variability in South Asia because most of the climate models could not represent the correlation between observed precipitation and ENSO (Annamalai et al. 2007). Therefore, the coupled RCM will be a helpful approach in future regional dynamic downscaling.

For the monsoon characteristics, the RCMs showed a close correspondence to the observations (Figs. 7 $\&$ 8). The monsoon is characterised by an annual 
reversal of the low-level winds and well-defined dry and wet seasons (Wang \& Ding 2008), the variability of which is of great importance for simulating future climate impacts (Wang 2006, Colman et al. 2011, Turner \& Annamalai 2012). The metric of annual mean precipitation, the $\mathrm{AC} 1$ and the $\mathrm{AC} 2$ are the basis for MPI and the monsoon domain. The accuracy of the MPI and the monsoon domain indicate the model performance in capturing the intra-seasonal rainfall variations. The MPI strongly depends on the difference in precipitation between the rainy and dry season. YSU-RSM showed insufficient skill in capturing the annual cycle, especially in the winter season over the SAS, the EAS and the WNP (Fig. 5). Hence, YSU-RSM showed the worst capacity to represent the AC1 and MPI (Fig. 8). Furthermore, the IPCC Fifth Assessment Report (AR5) indicated that multimodel ensemble means from Coupled Model Intercomparison Project phase 5 (CMIP5) almost failed to capture the MPI and the domain over the Western North Pacific-East Asia monsoon domain, whileits performance was improved when compared to CMIP3 (Flato et al. 2013). The RCMs better captured the monsoon characteristics over the Korean Peninsula, the Korea Strait and southern Japan than the CMIP5 models. High-resolution RCMs are able to show the topography and coastlines, resulting in a more advanced simulation of MPI and monsoon domain compared to the CMIP5 simulations.

Acknowledgements. This work was funded by the China Scholarship Council (CSC). We acknowledge the climate modelling groups listed in Table 1 of this paper for producing and making their model output available (http://cordex-ea. climate.go.kr/main/mainPage.do). We thank APHRODITE, CRU, GPCC, GPCP, TRMM and ECMWF for providing the observation datasets. The computational resources were made available by the German Climate Computing Center (DKRZ, https://www.dkrz.de/) through support from the BMBF. We appreciate the comments of 4 anonymous reviewers.

\section{LITERATURE CITED}

Adler RF, Huffman GJ, Chang A, Ferraro R and others (2003) The version-2 global precipitation climatology project (GPCP) monthly precipitation analysis (1979present). J Hydrometeorol 4:1147-1167

Annamalai H, Hamilton K, Sperber KR (2007) The south Asian summer monsoon and its relationship with ENSO in the IPCC AR4 simulations. J Clim 20:1071-1092

Arakawa A, Lamb VR (1981) A potential enstrophy and energy conserving scheme for the shallow-water equations. Mon Weather Rev 109:18-36

Baldauf M, Schulz J (2004) Prognostic precipitation in the Lokal Modell (LM) of DWD. COSMO Newsl 4:177-180

Bonan GB, Oleson KW, Vertenstein M, Levis S and others (2002) The land surface climatology of the community land model coupled to the NCAR community climate model. J Clim 15:3123-3149

Briegleb BP (1992) Longwave band model for thermalradiation in climate studies. J Geophys Res Atmos 97: 11475-11485

Chen F, Dudhia J (2001) Coupling an advanced land surface-hydrology model with the Penn State-NCAR MM5 modeling system. I. Model implementation and sensitivity. Mon Weather Rev 129:569-585

> Chou MD (1992) A solar-radiation model for use in climate studies. J Atmos Sci 49:762-772

> Chou MD, Lee KT, Tsay SC, Fu Q (1999) Parameterization for cloud longwave scattering for use in atmospheric models. J Clim 12:159-169

Christensen JH, Krishna Kumar K, Aldrian E, An SI and others (2013) Climate phenomena and their relevance for future regional climate change. In: Stocker TF, Qin DH, Plattner GK, Tignor $\mathrm{M}$ and others (eds) Climate change 2013: the physical science basis. Contribution of Working Group I to the Fifth Assessment Report of the Intergovernmental Panel on Climate Change. Cambridge University Press, Cambridge, p 1229-1231

> Colman RA, Moise AF, Hanson LI (2011) Tropical Australian climate and the Australian monsoon as simulated by 23 CMIP3 models. J Geophys Res Atmos 116:D101116, doi: 10.1029/2010JD015149

Cusack S, Slingo A, Edwards JM, Wild M (1998) The radiative impact of a simple aerosol climatology on the Hadley Centre atmospheric GCM. QJR Meteorol Soc 124: 2517-2526

Cusack S, Edwards JM, Crowther JM (1999) Investigating k distribution methods for parameterizing gaseous absorption in the Hadley Centre climate model. J Geophys Res Atmos 104:2051-2057

> Davies HC, Turner RE (1977) Updating prediction models by dynamical relaxation-examination of technique. QJR Meteorol Soc 103:225-245

- Davies T, Cullen MJP, Malcolm AJ, Mawson MH, Staniforth A, White AA, Wood N (2005) A new dynamical core for the Met Office's global and regional modelling of the atmosphere. QJR Meteorol Soc 131:1759-1782

> Dee DP, Uppala SM, Simmons AJ, Berrisford P and others (2011) The ERA-Interim reanalysis: configuration and performance of the data assimilation system. QJR Meteorol Soc 137:553-597

> Ding YH, Chan JCL (2005) The east Asian summer monsoon: an overview. Meteorol Atmos Phys 89:117-142

> Druyan LM, Feng JM, Cook KH, Xue YK and others (2010) The WAMME regional model intercomparison study. Clim Dyn 35:175-192

> Edwards JM, Slingo A (1996) Studies with a flexible new radiation code. 1 . Choosing a configuration for a largescale model. QJR Meteorol Soc 122:689-719

Emanuel KA (1991) A scheme for representing cumulus convection in large-scale models. J Atmos Sci 48: 2313-2335

> Emanuel KA, Zivkovic-Rothman M (1999) Development and evaluation of a convection scheme for use in climate models. J Atmos Sci 56:1766-1782

> Essery R, Pomeroy J, Parviainen J, Storck P (2003) Sublimation of snow from coniferous forests in a climate model. J Clim 16:1855-1864

> Fischer T, Menz C, Su B, Scholten T (2013) Simulated and projected climate extremes in the Zhujiang river basin, south China, using the regional climate model COSMOCLM. Int J Climatol 33:2988-3001

Flato G, Marotzke J, Abiodun B, Braconnot P and others (2013) Evaluation of climate models. In: Stocker TF, Qin 
DH, Plattner GK, Tignor $M$ and others (eds) Climate change 2013: the physical science basis. Contribution of Working Group I to the Fifth Assessment Report of the Intergovernmental Panel on Climate Change. Cambridge University Press, Cambridge, p 810-815

Fu CB, Wang SY, Xiong Z, Gutowski WJ and others (2005) Regional climate model intercomparison project for Asia. Bull Am Meteorol Soc 86:257-266

Gao XJ, Xu Y, Zhao ZC, Pal JS, Giorgi F (2006) On the role of resolution and topography in the simulation of east Asia precipitation. Theor Appl Climatol 86:173-185

Gao X, Shi Y, Song R, Giorgi F, Wang Y, Zhang D (2008) Reduction of future monsoon precipitation over China: comparison between a high resolution RCM simulation and the driving GCM. Meteorol Atmos Phys 100:73-86

Gao XJ, Shi Y, Giorgi F (2011) A high resolution simulation of climate change over China. Sci China Earth Sci 54: $462-472$

Gao X, Shi Y, Zhang D, Wu J, Giorgi F, Ji Z, Wang Y (2012) Uncertainties in monsoon precipitation projections over China: results from two high-resolution RCM simulations. Clim Res 52:213-226

Gao XJ, Wang ML, Filippo G (2013) Climate change over China in the 21st century as simulated by BCC_CSM1.1RegCM4.0. Atmos Ocean Sci Lett 6:381-386

Gbobaniyi E, Sarr A, Sylla MB, Diallo I and others (2014) Climatology, annual cycle and interannual variability of precipitation and temperature in CORDEX simulations over west Africa. Int J Climatol 34:2241-2257

Giorgi F, Marinucci MR, Bates GT (1993) Development of a 2nd-generation regional climate model (Regcm2). 1. Boundary-layer and radiative-transfer processes. Mon Weather Rev 121:2794-2813

Giorgi F, Jones C, Asrar GR (2009) Addressing climate information needs at the regional level: the CORDEX framework. WMO Bull 58:175-183

Giorgi F, Coppola E, Solmon F, Mariotti L and others (2012) RegCM4: model description and preliminary tests over multiple CORDEX domains. Clim Res 52:7-29

Grant ALM, Brown AR (1999) A similarity hypothesis for shallow-cumulus transports. QJR Meteorol Soc 125:1913-1936

Gregory D, Rowntree PR (1990) A mass flux convection scheme with representation of cloud ensemble characteristics and stability-dependent closure. Mon Weather Rev 118:1483-1506

Grell GA, Dudhia J, Stauffer D (1994) A description of the fifth-generation Penn State/NCAR mesoscale model (MM5). NCAR Tech Note NCAR/TN-398+STR. National Center for Atmospheric Research, Boulder, CO

- Hargreaves JC, Annan JD (2014) Can we trust climate models? Wiley Interdiscip Rev Clim Chang 5:435-440

> Harris I, Jones PD, Osborn TJ, Lister DH (2014) Updated high-resolution grids of monthly climatic observations the CRU TS3.10 dataset. Int J Climatol 34:623-642

Hewitt HT, Copsey D, Culverwell ID, Harris CM and others (2011) Design and implementation of the infrastructure of HadGEM3: the next-generation Met Office climate modelling system. Geosci Model Dev 4:223-253

> Holtslag AAM, Debruijn EIF, Pan HL (1990) A highresolution air-mass transformation model for short-range weather forecasting. Mon Weather Rev 118:1561-1575

Hong SY, Kanamitsu M (2014) Dynamical downscaling: fundamental issues from an NWP point of view and recommendations. Asia-Pac J Atmos Sci 50:83-104

Hong SY, Pan HL (1998) Convective trigger function for a mass-flux cumulus parameterization scheme. Mon Weather Rev 126:2599-2620
Hong SY, Juang HMH, Zhao QY (1998) Implementation of prognostic cloud scheme for a regional spectral model. Mon Weather Rev 126:2621-2639

> Hong SY, Noh Y, Dudhia J (2006) A new vertical diffusion package with an explicit treatment of entrainment processes. Mon Weather Rev 134:2318-2341

> Hong SY, Park H, Cheong HB, Kim JEE and others (2013) The global/regional integrated model system (GRIMs). Asia-Pac J Atmos Sci 49:219-243

Hourdin F, Musat I, Guichard F, Ruti PM and others (2010) AMMA-model intercomparison project. Bull Am Meteorol Soc 91:95-104

Huffman GJ, Adler RF, Bolvin DT, Gu GJ and others (2007) The TRMM multisatellite precipitation analysis (TMPA): quasi-global, multiyear, combined-sensor precipitation estimates at fine scales. J Hydrometeorol 8:38-55

Hui TW, Shum KY (2005) Prediction of seasonal rainfall in Hong Kong using ECPC's regional climate model. The 6th International RSM Workshop, Palisades, NY, 11-15 July 1005. Available at www.weather.gov.hk/publica/ reprint/r602.pdf

IPCC (Intergovernmental Panel on Climate Change) (2013) Climate change 2013: the physical science basis. Summary for policymakers. Contribution of Working Group I to the Fifth Assessment Report of the Intergovernmental Panel on Climate Change. Cambridge University Press, Cambridge, p 3-29

Jacobsen I, Heise E (1982) A new economic method for the computation of the surface temperature in numerical models. Contrib Atmos Phys 55:128-141

Jiang P, Gautam MR, Zhu JT, Yu ZB (2013) How well do the GCMs/RCMs capture the multi-scale temporal variability of precipitation in the southwestern United States? J Hydrol (Amst) 479:75-85

Juang HMH, Kanamitsu M (1994) The NMC nested regional spectral model. Mon Weather Rev 122:3-26

Juang HMH, Hong SY, Kanamitsu M (1997) The NCEP regional spectral model: an update. Bull Am Meteorol Soc 78:2125-2143

Kain JS, Fritsch JM (1990) A one-dimensional entraining detraining plume model and its application in convective parameterization. J Atmos Sci 47:2784-2802

Kiehl JT, Hack JJ, Bonan GB, Boville BA, Briegleb BP, Williamson DL, Rasch PJ (1996) Description of the NCAR community climate model (CCM3). NCAR Tech Note NCAR/TN-420+STR:143. National Center for Atmospheric Research, Boulder, CO

Laprise R (2008) Regional climate modelling. J Comput Phys 227:3641-3666

> Leduc M, Laprise R (2009) Regional climate model sensitivity to domain size. Clim Dyn 32:833-854

> Lee DK, Cha DH, Kang HS (2004) Regional climate simulation of the 1998 summer flood over east Asia. J Meteorol Soc Jpn 82:1735-1753

Lee DK, Cha DH, Jin CS, Choi SJ (2013) A regional climate change simulation over east Asia. Asia-Pac J Atmos Sci 49:655-664

> Lee JW, Hong SY (2014) Potential for added value to downscaled climate extremes over Korea by increased resolution of a regional climate model. Theor Appl Climatol 117:667-677

Lee JW, Hong SY, Chang EC, Suh MS, Kang HS (2014) Assessment of future climate change over east Asia due to the RCP scenarios downscaled by GRIMs-RMP. Clim Dyn 42:733-747

Lee JY, Wang B (2014) Future change of global monsoon in the CMIP5. Clim Dyn 42:101-119 
Lock AP, Brown AR, Bush MR, Martin GM, Smith RNB (2000) A new boundary layer mixing scheme. I. Scheme description and single-column model tests. Mon Weather Rev 128:3187-3199

Lynn BH, Khain AP, Dudhia J, Rosenfeld D, Pokrovsky A, Seifert A (2005) Spectral (bin) microphysics coupled with a mesoscale model (MM5). I. Model description and first results. Mon Weather Rev 133:44-58

- Martin GM, Ringer MA, Pope VD, Jones A, Dearden C, Hinton TJ (2006) The physical properties of the atmosphere in the new Hadley Centre global environmental model (HadGEM1). I. Model description and global climatology. J Clim 19:1274-1301

> Nikulin G, Jones C, Giorgi F, Asrar G and others (2012) Precipitation climatology in an ensemble of CORDEX-Africa regional climate simulations. J Clim 25:6057-6078

Oh SG, Park JH, Lee SH, Suh MS (2014) Assessment of the RegCM4 over East Asia and future precipitation change adapted to the RCP scenarios. J Geophys Res Atmos 119: 2913-2927

Paeth H, Hall NMJ, Gaertner MA, Alonso MD and others (2011) Progress in regional downscaling of west African precipitation. Atmos Sci Lett 12:75-82

Pal JS, Small EE, Eltahir EAB (2000) Simulation of regionalscale water and energy budgets: representation of subgrid cloud and precipitation processes within RegCM. J Geophys Res 105:29579-29594

Qian Y, Leung LR (2007) A long-term regional simulation and observations of the hydroclimate in China. J Geophys Res Atmos 112:D14104, doi:10.1029/2006JD008134

Redelsperger JL, Thorncroft CD, Diedhiou A, Lebel T, Parker DJ, Polcher J (2006) African monsoon multidisciplinary analysis - an international research project and field campaign. Bull Am Meteorol Soc 87:1739-1746

Reisner J, Rasmussen RM, Bruintjes RT (1998) Explicit forecasting of supercooled liquid water in winter storms using the MM5 mesoscale model. QJR Meteorol Soc 124: 1071-1107

Ritter B, Geleyn JF (1992) A comprehensive radiation scheme for numerical weather prediction models with potential applications in climate simulations. Mon Weather Rev 120:303-325

Rockel B, Will A, Hense A (2008) The regional climate model COSMO-CLM (CCLM). Meteorol Z 17:347-348

Rummukainen M (2010) State-of-the-art with regional climate models. Wiley Interdiscip Rev Clim Chang 1:82-96

Ruti PM, Williams JE, Hourdin F, Guichard F and others (2011) The west African climate system: a review of the AMMA model inter-comparison initiatives. Atmos Sci Lett 12:116-122

Schär C, Leuenberger D, Fuhrer O, Luthi D, Girard C (2002) A new terrain-following vertical coordinate formulation for atmospheric prediction models. Mon Weather Rev 130:2459-2480

Schneider U, Becker A, Finger P, Meyer-Christoffer A, Ziese M, Rudolf B (2014) GPCC's new land surface precipitation climatology based on quality-controlled in situ data and its role in quantifying the global water cycle. Theor Appl Climatol 115:15-40

Smith RK, Ulrich W, Dietachmayer G (1990) A numerical study of tropical cyclone motion using a barotropic model. 1. The role of vortex asymmetries. QJR Meteorol

Editorial responsibility: Filippo Giorgi,

Trieste, Italy
Soc $116: 337-362$

Staniforth A (1997) Regional modeling: a theoretical discussion. Meteorol Atmos Phys 63:15-29

> Steiner AL, Pal JS, Rauscher SA, Bell JL and others (2009) Land surface coupling in regional climate simulations of the west African monsoon. Clim Dyn 33:869-892

> Stephens GL, Li JL, Wild M, Clayson CA and others (2012) An update on Earth's energy balance in light of the latest global observations. Nat Geosci 5:691-696

Sylla MB, Giorgi F, Ruti PM, Calmanti S, Dell'Aquila A (2011) The impact of deep convection on the west African summer monsoon climate: a regional climate model sensitivity study. QJR Meteorol Soc 137:1417-1430

- Tiedtke M (1989) A comprehensive mass flux scheme for cumulus parameterization in large-scale models. Mon Weather Rev 117:1779-1800

Turner AG, Annamalai H (2012) Climate change and the south Asian summer monsoon. Nat Clim Change 2: 587-595

- Uppala SM, Kallberg PW, Simmons AJ, Andrae U and others (2005) The ERA-40 re-analysis. QJR Meteorol Soc 131: 2961-3012

von Storch H, Langenberg H, Feser F (2000) A spectral nudging technique for dynamical downscaling purposes. Mon Weather Rev 128:3664-3673

Wang B (2006) The Asian monsoon. Springer Science+ Business Media, New York, NY

Wang B, Ding QH (2008) Global monsoon: dominant mode of annual variation in the tropics. Dyn Atmos Oceans 44: 165-183

> Wang B, Wu RG, Fu XH (2000) Pacific-east Asian teleconnection: How does ENSO affect East Asian climate? J Clim 13:1517-1536

> Wang B, Kim HJ, Kikuchi K, Kitoh A (2011) Diagnostic metrics for evaluation of annual and diurnal cycles. Clim Dyn 37:941-955

Wang D, Menz C, Simon T, Simmer C, Ohlwein C (2013) Regional dynamical downscaling with CCLM over East Asia. Meteorol Atmos Phys 121:39-53

- Wang YQ, Leung LR, McGregor JL, Lee DK, Wang WC, Ding YH, Kimura F (2004) Regional climate modeling: progress, challenges, and prospects. J Meteorol Soc Jpn 82:1599-1628

Wilson DR, Ballard SP (1999) A microphysically based precipitation scheme for the UK meteorological office unified model. QJR Meteorol Soc 125:1607-1636

Wu J, Gao XJ, Shi Y, Filippo G (2011) Climate change simulation over Xinjiang region in 21st century by a high resolution RCM. J Glaciol Geocryol 33:479-487 (in Chinese with English abstract)

Xue YK, De Sales F, Lau WKM, Boone A and others (2010) Intercomparison and analyses of the climatology of the West African Monsoon in the West African Monsoon Modeling and Evaluation project (WAMME) first model intercomparison experiment. Clim Dyn 35:3-27

> Yatagai A, Arakawa O, Kamiguchi K, Kawamoto H, Nodzu MI, Hamada A (2009) A 44-year daily gridded precipitation dataset for Asia based on a dense network of rain gauges. SOLA 5:137-140

Yu ET, Wang HJ, Sun JQ (2010) A quick report on a dynamical downscaling simulation over China using the nested model. Atmos Oceanic Sci Lett 3:325-329

Submitted: September 15, 2014; Accepted: April 7, 2015

Proofs received from author(s): July 9, 2015 